IZA DP No. 7483

Men Vote in Mars, Women Vote in Venus:

A Survey Experiment in the Field

Vincenzo Galasso

Tommaso Nannicini

July 2013 


\title{
Men Vote in Mars, Women Vote in Venus: A Survey Experiment in the Field
}

\author{
Vincenzo Galasso \\ Università della Svizzera Italiana, \\ IGIER and CEPR \\ Tommaso Nannicini \\ Bocconi University, \\ IGIER and IZA
}

Discussion Paper No. 7483
July 2013

IZA

P.O. Box 7240

53072 Bonn

Germany

Phone: +49-228-3894-0

Fax: +49-228-3894-180

E-mail: iza@iza.org

Any opinions expressed here are those of the author(s) and not those of IZA. Research published in this series may include views on policy, but the institute itself takes no institutional policy positions. The IZA research network is committed to the IZA Guiding Principles of Research Integrity.

The Institute for the Study of Labor (IZA) in Bonn is a local and virtual international research center and a place of communication between science, politics and business. IZA is an independent nonprofit organization supported by Deutsche Post Foundation. The center is associated with the University of Bonn and offers a stimulating research environment through its international network, workshops and conferences, data service, project support, research visits and doctoral program. IZA engages in (i) original and internationally competitive research in all fields of labor economics, (ii) development of policy concepts, and (iii) dissemination of research results and concepts to the interested public.

IZA Discussion Papers often represent preliminary work and are circulated to encourage discussion. Citation of such a paper should account for its provisional character. A revised version may be available directly from the author. 


\section{ABSTRACT \\ Men Vote in Mars, Women Vote in Venus: A Survey Experiment in the Field ${ }^{*}$}

This paper investigates the differential response of male and female voters to competitive persuasion in political campaigns. During the 2011 municipal elections in Milan, a sample of eligible voters was randomly divided into three groups. Two were exposed to the same incumbent's campaign but to different opponent's campaigns, with either a positive or a negative tone. The third - control - group received no electoral information. The campaigns were administered online and consisted of a bundle of advertising tools (videos, texts, slogans). Stark gender differences emerge. Negative advertising increases men's turnout, but has no effect on women. Females, however, vote more for the opponent and less for the incumbent when they are exposed to the opponent's positive campaign. Exactly the opposite occurs for males. Additional tests show that our results are not driven by gender identification with the candidate, ideology, or other voter's observable attributes. Effective strategies of persuasive communication should thus take gender into account. Our results may also help to reconcile the conflicting evidence on the effect of negative vs. positive advertising, as the average impact may wash out when aggregated across gender.

JEL Classification: D72, J16, M37

Keywords: gender differences, political campaigns, competitive persuasion

Corresponding author:

Tommaso Nannicini

Bocconi University

Department of Economics

Via Rontgen 1

20136 Milan

Italy

E-mail: tommaso.nannicini@unibocconi.it

\footnotetext{
* We thank Guido Tabellini for encouragement and insightful suggestions on an earlier version of this project, as well as Manuel Bagues, Stefania Borghini, Christopher Kam, Paola Profeta, and seminar participants at CEPR Public Policy Symposium 2013, Collegio Carlo Alberto, EPSA Conference 2013, IGIER-Bocconi, Lisbon, Lucern, USI Lugano, ZEW Mannheim, and Zurich for their helpful comments. Maria Carreri, Monica Morlacco, and Teresa Talò provided excellent research assistance. We also thank Carlo Erminero at CE\&CO for conducting the surveys, and Davide Baldi at DUDE for producing the graphics and the videos. Financial support from the European Research Council (grant No. 230088 ) is gratefully acknowledged. The remaining errors are ours and follow a random walk.
} 


\section{Introduction}

Persuasion has long been deemed to be an art, and a very rewarding one. ${ }^{1}$ Persuading customers to purchase a new product, a recruiting committee to award a promotion, potential donors to contribute to a campaign, or citizens to vote for a candidate is a key to success in business, personal career, fund-raising, and politics. ${ }^{2}$ "Persuasive communication" involves one or more senders trying to influence the behavior of a set of receivers (DellaVigna and Gentzkow, 2010). Often, senders actively compete against each other to persuade receivers. ${ }^{3}$ A key decision in competitive persuasion is whether to run an aggressive campaign against rivals or to concentrate on self-promotion. For example, marketing strategies may range from pure brand promotion to comparative advertising, political campaigns may feature both positive and negative advertising, and even coworkers competing for promotion may choose to praise themselves or to belittle the others. This issue has been mainly addressed in political campaigns, where negative advertising is largely allowed, following the seminal experiment by Ansolabehere et al. (1994). However, no conclusive evidence emerges from the literature.

Persuasion styles are largely idiosyncratic, as they depend on the sender's characteristics. However, personal traits of the receivers might be just as important in determining how effective a campaign can be. Among these traits, gender seems the natural candidate. Do advertisers use the same arguments to convince female and male buyers? ${ }^{4}$ Or do parents raise their children using the same persuasion strategies for sons and daughters?

\footnotetext{
${ }^{1}$ According to Aristoteles and later to Plato, the art of persuasion consisted of five elements: "inventio," the research of the best arguments of persuasion; "dispositio," the internal organization of those arguments; "elocutio," the style of communicating them; "memoria," how to memorize arguments and responses to possible counter-arguments, and "actio," mimic or visual expression.

${ }^{2}$ Several evaluation studies suggest that persuasive communication matters, although the size of the effect varies across markets and campaign tools. For example, the experimental literature summarized in Green and Gerber (2004) shows that specific tools of political campaigns do affect turnout. In charity donations, DellaVigna, List, and Malmendier (2012) find a strong effect of door-to-door persuasive communication. Bertrand et al. (2010) randomize commercial mailers and show that advertising content affects demand. A different strand of this literature evaluates the role of news media on political outcomes (e.g., see DellaVigna and Kaplan, 2007; Gentzkow, Shapiro, and Sinkinson, 2011). See DellaVigna and Gentzkow (2010) for a review of the empirical evidence on persuasion.

${ }^{3}$ See Gentzkow and Kamenica (2011) for a theoretical framework where competition in persuasion increases the extent of information revealed.

${ }^{4}$ Studies on consumer behavior suggest that ads relating the advertised product to success over others positively affect males' intention to purchase (Prakash, 1992). On the other hand, males seem less likely to be convinced by marketing campaigns emphasizing the quality of the product (Vilela and Nelson, 2006).
} 
Little effort has been made to identify behavioral differences by gender in response to more or less aggressive communication strategies. A recent empirical literature suggests that gender differences do emerge both in the attitude toward competition and in the performance obtained in competitive environments (see Croson and Gneezy, 2009, and Bertrand, 2010, for a review). Should we expect males and females to react differently also as receivers of hostile (toward rivals) messages from competing senders? To tackle this question, we study gender differences in the response to competitive persuasion in a political campaign. We use a survey experiment in the field, run during the 2011 municipal election in Milan, to analyze the effect of positive vs. negative electoral campaigning on turnout and voting behavior of male and female voters. ${ }^{5}$

Our experiment was implemented by providing four surveys to an online sample of about 1,500 eligible voters. Respondents to the initial profiling survey, conducted at the end of March 2011, were randomly assigned to two treatment groups - positive vs. negative campaign - and to a control group exposed to no campaign at all. Individuals in the positive (negative) group were exposed to an electoral campaign with a positive (negative) tone by the main opponent, and to the actual (non-randomized) campaign by the incumbent, which was mainly perceived as negative by individuals in the control group.

We departure from existing studies on positive vs. negative campaigning by administering a "complete" electoral campaign. Previous experiments have typically randomized one single campaign tool, such as a video (Ansolabehere et al., 1994) or canvassing (Arceneaux and Nickerson, 2010). However, political campaigns are a bundle of different communication tools, which could potentially reinforce each other. ${ }^{6}$ To improve the intensity and realism of our informational treatments, we thus expose individuals in our sample to four devices of political persuasion: 1) a video interview with the candidate, 2) an electoral slogan, 3) an open letter to the voters, and 4) a video ad endorsed by the candidate. Each

\footnotetext{
${ }^{5}$ See Section 3 for a discussion of the experimental literature on negative campaigning in political science. Studies of political persuasion have emphasized characteristics of the receivers different from gender (Fridkin and Kenney, 2011), such as being a politician's core supporter (Glaeser, Ponzetto, and Shapiro, 2005), or the role of social networks in magnifying the effectiveness of political communication (Murphy and Shleifer, 2004). Gender has instead been widely studied as a politician's attribute, looking at its impact on public policy (Chattopadhyay and Duflo, 2004), party selection (Bagues and Esteve-Volart, 2012; Baltrunaite et al., 2012), or government duration (Gagliarducci and Paserman, 2012).

${ }^{6}$ For example, get-out-the-vote experiments show that mailers are often ineffective, but their impact may be amplified when they are combined with other campaign tools (Green and Gerber, 2004).
} 
of these items was proposed to the two treatment groups in a positive or in a negative tone. However, both positive and negative ads addressed the same issue, with the same format, and in the same setting (e.g., video images, length of the letter). The initial two treatment tools (video interview and campaign slogan) were provided with a second survey, run at the end of April 2011. The last two tools (open letter and video ad) were provided with a third survey, run in the week before the election. After administering each of the four tools, we used the corresponding survey to measure their instantaneous effect on the perceived credibility and approval rate of the candidates, as in a standard survey experiment.

The "in the field" component of our experimental design comes from collecting (selfdeclared) turnout and voting choices through a fourth survey, run in the days immediately after the May 15-16 election. These responses enable us to evaluate the overall effect of our randomized campaigns on electoral behavior.

Our empirical results unveil large differences in the gender response to political persuasion strategies. Male and female voters tend to respond in opposite ways to the degree of aggressiveness of the opponent's campaign. Negative advertising increases men's turnout by about 8 percentage points, but has no effect on women. Gender differences are even stronger for electoral choices. Females vote more for the opponent (by 8 points) and less for the incumbent (by 8 points) if exposed to the opponent's positive campaign. Exactly the opposite happens for males, who vote less for the opponent (by 11 points) and more for the incumbent (by 12.7 points) if exposed to the opponent's positive campaign. Overall, these effects amount to persuasion rates ranging from $21 \%$ to $24 \%$ depending on the outcome (see DellaVigna and Kaplan, 2007). The intensity of our bundle of informational treatments was hence strong, as these numbers fit in the upper tail of the distribution of persuasion rates unveiled so far in the literature.

Our experimental results suggest that gender matters in the response to competitive persuasion. When faced with political advertisement for an upcoming electoral competition, male and female behaviors differ. But why? Several channels may be at work. Voters may cluster along gender identity line (see Akerlof and Kranton, 2000). In particular, since the 2011 election in Milan was a mixed gender race between a female incumbent and a male opponent, women might have particularly disliked a negative campaign by a man against 
a woman. However, we can exploit a "natural" experiment that took place during our third survey to rule out this identity channel. During a campaign debate on Sky TV, the (female) incumbent - Letizia Moratti - violently attacked the (male) opponent - Giuliano Pisapia - by accusing him of having been tied with communist terrorists in his youth. This debate was aired on May 11, during our third survey, which took place between May 6 and 14. By comparing the responses of individuals who happened to answer the survey just before or just after the show was aired, we find that again males and females have opposite reactions. Males lean more toward the (female) sender of the negative attack, and females align with the (male) candidate targeted by the attack. Hence, gender identification does not seem to be a first-order mechanism in our sample.

Another potential channel of the differential gender response to our treatments is that males and females may differ along other relevant characteristics. In particular, women have been shown to have higher preferences for redistribution and to be more left leaning (see Edlund and Pande, 2002). This correlation is indeed confirmed in our sample. Yet, ideology - as well as all other observable characteristics that differ across gender in our data - only partially account for the higher responsiveness of women to the positive campaign run by the left-wing candidate (the opponent). After controlling for ideology and the other observables, gender differences, albeit attenuated, still persist.

These (residual) differences might be interpreted according to the existing economic and neuro-psychological literature (see Croson and Gneezy, 2009, and Bertrand, 2010, for a review). Females have been shown to shy away from competition when they are active players. Our results may suggest that this effect carries over also when they are passive receivers of messages of competitive persuasion. Hence, women may just have a lower taste for competition, especially if aggressive, rather than their shying away from competition being driven for instance by higher risk aversion (see Niederle and Vesterlund, 2007). As a result, effective strategies of persuasive communication should tailor the aggressiveness of their messages to the gender of the potential receivers.

The paper is organized as follows. The next section provides a brief background description of the 2011 Milan election. Section 3 describes the experimental design. Section 4 analyzes the main empirical results and the potential mechanisms in relation to the existing literature. Section 5 concludes. All questionnaires, campaign materials, and videos 
can be downloaded at www.people.eco.usi.ch/galassov. Short descriptions and English translations of the (randomized) campaign tools are in the Appendix.

\section{Political Background}

The two main candidates in the 2011 municipal election in Milan were Letizia Moratti, the incumbent mayor supported by a center-right coalition, and Giuliano Pisapia, her main opponent supported by a center-left coalition. Letizia Moratti had first been elected mayor in May 2006. Since 1993, the Italian electoral system for cities above 15,000 inhabitants features direct election of the mayor, with a runoff between the best two candidates if none of them obtains the majority of the votes in the first round. The city council is elected under proportional representation with majority premium. In May 2006, Letizia Moratti was elected at the first round with $52 \%$ of the votes.

During her five-year term as mayor of Milan, Ms. Moratti introduced a pollution charge for cars entering the city center. She was also active in promoting the candidacy of Milan to host the Expo 2015, which was in fact awarded to the city in March 2008. She was hardly criticized for her spoil-system; upon her arrival, in fact, she fired several municipal managers and replaced them with high-wage external consultants. She was often accused of absenteeism, as she failed to participate to around $95 \%$ of the official meetings of the city council. These were among the main issues of the 2011 electoral campaign.

Giuliano Pisapia announced his candidacy to mayor of Milan as soon as June 2010. In November 2010, he - somewhat unexpectedly-won the center-left coalition primary elections with $45 \%$ of the votes against Stefano Boeri (40\%), who was officially supported by the Democratic Party, the main party in the coalition. ${ }^{7}$ At the beginning of the electoral campaign, Ms. Moratti was considered to have a large electoral advantage. In fact, besides the usual incumbency advantage, she could count on a solid center-right electorate, as Milan had been run by a center-right mayor for eighteen consecutive years.

Ms. Moratti took advantage of her family wealth to run an expensive electoral campaign on all media outlets, as already done in 2006. Her electoral campaign was largely perceived as negative, with frequent attacks against her main political opponent. The highlight of

\footnotetext{
${ }^{7} \mathrm{Mr}$. Pisapia had previously been elected to the lower house of the Italian Parliament in 1996 and again in 2001, in the electoral list of the Communist Party ("Rifondazione Comunista").
} 
such a negative campaign occurred a few days before the election, on May 11, during a Sky TV debate. In her closing statement - to which she knew Mr. Pisapia would have been unable to reply-Ms. Moratti accused her opponent of having taken part to a car robbery with other communist terrorists in his youth. After the recording of the debate, Mr. Pisapia explained that he had been fully and immediately acquitted from the charge, and announced his intention (not carried out) to sue the mayor. On the contrary, the style of Mr. Pisapia's electoral campaign was very accommodating. He portrayed himself as a gentle force and concentrated his campaigning effort on social networks.

This difference in campaigning styles was clearly recognized by individuals in our control group. As a matter of fact, $76 \%$ of the respondents in the control group perceive Ms. Moratti's campaign as negative, while only $22 \%$ perceive Mr. Pisapia's campaign as such. Interestingly, no gender differences in these perceptions emerge among eligible voters not exposed to our informational treatments.

At the first round of the 2011 election, which took place on May 15-16, Mr. Pisapia obtained $48 \%$ of the votes, against $41.6 \%$ for Ms. Moratti. Mr. Pisapia then went on to win the runoff ballot on May 29-30, receiving $55.1 \%$ of the votes, and became mayor of Milan. The turnout rate was $67.6 \%$ in the first round and $67.2 \%$ in the runoff.

\section{Experimental Design}

We examine the effects of positive vs. negative campaigning on a sample of (male and female) eligible voters, who accepted to participate in a series of online surveys prior to the election for mayor of Milan in May 2011. Unlike the existing experimental literature, we randomly administered a "complete" electoral campaign, consisting of several advertising items. This increases the strength, and the realism, of our treatment, but at the price of reducing the possibility of pinning down the effect of each campaign tool. Specifically, we randomized our positive vs. negative treatment over four items of the opponent's electoral campaign: 1) a video interview with the candidate; 2) a campaign slogan; 3) a letter to the voters signed by the candidate; and 4) an electoral video ad endorsed by the candidate. All of these tools were designed by professionals under our direction and in collaboration with the opponent's campaign. Clearly, the informational treatments coexisted with the real campaign, going on independently of our surveys, and therefore their effects (if any) 
operated at the margin. However, we designed the experiment so that the intensity of the overall treatment could be strong, as different campaign items with the same tone might reinforce each other (see Green and Gerber, 2004), especially on individuals who did not want or did not have time to follow the real campaign closely.

Our strategy represents a departure from the previous political science literature on negative advertisement, where only one single element of the electoral campaign has typically been randomized. ${ }^{8}$ We do however follow this literature in the design of each single ad, as we kept the format fixed and just changed the tone of the content (positive vs. negative). In their seminal paper on negative campaigning, Ansolabehere et al. (1994) exposed a (non-random) sample of 1,655 eligible voters in three electoral races in California (1990 California governor, 1992 US Senate, and 1993 Los Angeles mayor) to a single (positive vs. negative) political ad, aired during a commercial break. Using responses from a posttest questionnaire, they found that the negative ad reduced average voting intentions by 5\%. In a more recent field experiment, Arceneaux and Nickerson (2010) had volunteers personally delivering a political message to their treatment groups to find that, while canvassing is effective in influencing voters, there is little evidence of a differential effect between negative and positive campaigning. ${ }^{9}$

As described in Figure 1, our experiment was implemented between March and May 2011 by providing four surveys to the eligible voters in our online sample. The first survey was conducted between March 28 and April 4 for all individuals in our sample with the goal of obtaining relevant personal information and the individuals' political and social attitudes. Respondents to the initial survey were then randomly assigned to three groups.

\footnotetext{
${ }^{8}$ More generally, the effectiveness of electoral campaigns in mature democracies is the subject of a large literature, including, among others, Ansolabehere et al. (1994), Ansolabehere and Iyengar (1995), Gerber and Green (2000), Green and Gerber (2004), Gerber, Green, and Shachar (2003), Nickerson (2008), and Dewan, Humphreys, and Rubenson (2010). Typically, these studies rely on either small scale experiments for partisan ads, or on large scale non-partisan campaigns for turnout. For large scale (randomized) partisan campaigns, see Gerber et al. (2011) and Kendall, Nannicini, and Trebbi (2013).

${ }^{9}$ Other studies on negative campaigning use a different methodology: they pool together aggregate data on turnout and survey data, and classify the negativity of the actual electoral campaign advertisement. Most of these papers find either no impact of negative campaigning (Wattenberg and Brians, 1999), or even supporting evidence for a "stimulation" effect on electoral turnout (Finkel and Geer, 1998; Freedman and Goldstein, 1999; Kahn and Kenney, 1999; Goldstein and Freedman, 2002; Clinton and Lapinski, 2004; and Brooks and Geer, 2007). A meta-analytic assessment of this growing literature by Lau et al. (2007) finds inconclusive results: negative political campaigns are neither effective to win votes, although they may be more memorable and enhance knowledge, nor they seem to depress turnout.
} 
Individuals in group A were exposed to the positive treatment, consisting of an electoral campaign with a positive tone by the opponent; individuals in group B to the negative treatment, consisting of an electoral campaign with a negative tone by the opponent; while individuals in groups $\mathrm{C}$ received no electoral information. All individuals in groups $\mathrm{A}$ and B also observed a (non-randomized) electoral campaign by the incumbent, composed of items extracted from the incumbent's actual campaign.

Between April 26 and May 2, the second survey was conduced, but only for individuals in the treatment groups (A and B). This survey contained the first wave of the electoral campaign: the video interview and the campaign slogan. The third survey was releasedagain to groups A and B only-between May 6 and 14, and contained the second wave of the electoral campaign: the open letter to the citizens and the video ad.

It is worth noting that the Sky TV debate, in which Ms. Moratti violently attacked Mr. Pisapia, occurred on May 11, and thus during our third survey. We will return to this issue and exploit this variation in Section 4.2. The municipal elections took place on May 15 and 16. The (fourth and last) post-electoral survey was conducted for all three groups immediately after the election, starting on May 17, and lasted for a week. This survey collected information on self-reported electoral outcomes (such as turnout and actual vote for the candidates), voting intentions regarding the runoff election, and personal perceptions about the electoral campaign. ${ }^{10}$

\subsection{Our Sample}

We conducted our experiment using an online panel of eligible voters for the upcoming election. A Milan-based commercial survey company ("CE\&Co") was contacted to run the online surveys. They used different techniques (such as exploiting their existing online panel, or producing new contacts using phone books, etc.) to construct an initial sample of about 1,500 eligible voters, aged between 18 and 65, in the 2011 election for mayor in Milan. The first survey was administrated with the goal of obtaining relevant personal information (gender, age, marital status, education), as well as more specific information on political and social attitudes (political orientation, voting behavior in previous local and national elections, exposure to the media, knowledge of local politics and of local

\footnotetext{
${ }^{10}$ All surveys are available online at www.people.usi.ch/galassov/projects.html.
} 
news). The respondents to the initial survey were then randomly assigned to our three groups, that is, the two treatment groups and the control group.

The main characteristics of our sample are summarized in Table 1, which provides descriptive statistics by treatment group. Besides standard demographic characteristics and education, we measure the ideological position of each voter, her interest in politics, and her knowledge about local politics ("did not know mayor" meaning that she misreported the name of the incumbent mayor). All variables but the nonresponse dummy come from the first (pre-treatment) survey. Our sample is largely composed of females (59\%), college graduates (44\%), and married individuals (48\%). There is a large share of individuals younger than 30 years $(23 \%)$, and only very few respondents have a low interest in politics $(4 \%)$ or did not know the name of the mayor $(3 \%)$. Our sample, of course, was not representative of the electorate aged from 18 to 65 years in the 2011 Milan election, as it is difficult to convince certain demographic groups to participate in online surveys. The internal validity of the experimental design, however, is guaranteed by the randomization protocol. Table 2 shows that all of these observable characteristics are balanced across treatment groups, with the only exception of the information measure at the $10 \%$ significance level. In particular, the attrition rate caused by nonresponses to the future surveys (something that we could not check ex ante) is also balanced across groups. This confirms the (ex post) validity of the experimental design.

\subsection{Informational Treatments}

We exposed individuals in the treatment groups to an entire electoral campaign by the opponent composed of four electoral tools either with a positive (group A) or a negative (group B) tone. All individuals in the two treatment groups were also exposed to the same electoral campaign by the incumbent, again characterized by the same four electoral tools. We now describe our informational treatments.

The first tool of the opponent's randomized campaign was a 100-second video interview to the candidate sitting at his office desk. The second tool was the opponent's main campaign slogan. The third tool was a letter to the voters, which described the opponent's main projects for the future of Milan or charged the incumbent for her mistakes while in office. The final tool was a 60 -second video ad endorsed by the opponent on relevant issues 
for the city (transportation, pollution, Expo). Each of these campaign tools addressed the same issues, with the same format and in the same setting, and was proposed in either a positive or a negative tone. The videos and all graphical information were realized by professionals and are available online at www.people.usi.ch/galassov/projects.html. In the Appendix, we provide further details and the English translation of the texts.

\section{Video Interview with the Candidate}

The 100-second videos featured a (single question) interview with the opponent, Giuliano Pisapia, sitting at his desk in his lawyer office. In both the positive and negative version of the video, the opponent addressed four issues: (i) public transportation, (ii) use of bikes, (iii) restrictions to use of the car, and (iv) green areas and parks. After an initial question asked by the same female voice, the candidate response lasted the entire length of the videos. Both videos showed the opponent wearing a white shirt and a tie at his desk, with a large bookshelf behind him for fifty percent of the time, as they were recorded on the same occasion. For the remaining time, his background voice was accompanied by imagines of traffic, bikes, public transportation, and parks in Milan.

The video with the positive tone-focused on the candidate's proposals on the above topics - ran under the header "my ideas for Milan." The video with the negative tonefocused on the incumbent's main missteps on the same topics during her tenure in officeran instead under the header "Moratti's mistakes." The texts of both interviews are in the Appendix. After each video, a question measured the impact reaction of the respondents to the message ("do you agree with what the candidate says in the video?").

\section{Electoral Campaign Slogan}

The main electoral campaign slogan was shown in a separate page of the survey in a large font and orange (the opponent's electoral campaign color) and black colors. In the positive tone campaign (group A), the slogan was "Pisapia for Mayor = Less Traffic \& More Green. A Change for Milan is Possible." In the negative tone campaign (group B), the slogan instead was "5 Years of Moratti = More Traffic \& Less Green. A Change for Milan is Possible." Appendix Figures A1 and A2 report the original slogans. Each slogan was followed by a question aimed at measuring the respondent's impact reaction ("in general, how much do you feel you can trust Giuliano Pisapia?"). 


\section{Open Letter to Voters}

The third tool of the electoral campaign was a one-page (almost two-hundred words long) letter to the voters, signed by the opponent, Giuliano Pisapia. In the initial part of the letter, which was common to both treatments, the opponent expressed his view that the primary duty of a mayor is to increase the wellbeing of the citizens. Then, both in the letter with the positive and the negative tone, he touched upon four issues: (i) clean air; (ii) work ethics; (iii) public transportation; and (iv) involvement of the citizens.

The letter with the positive tone ran (to group A) under the header "this is my commitment with the city," and ended with a positive plea: "Milan deserves to become once again one of the capitals of Europe." The letter with the negative tone ran (to group B) under the header "Milan does not deserve to be led by Ms. Moratti," and ended with a negative plea: "Milan does not deserve other five years of Moratti administration." The English translations of both letters are in the Appendix. After each letter, respondents were asked to evaluate the main message ("abstracting from your political viewpoint, how much do you agree with the general sense of this letter?").

\section{Video Ad Endorsed by the Candidate}

The last tool of the electoral campaign consisted of a 60 -second video of political advertisement realized by professionals and endorsed by the opponent. Both (positive and negative) videos showed images of Milan (such as traffic situations, public transportation, people walking on the streets, the city center, and parks) recorded on the same occasion. The same (professional) speaker read statements on four issues, while relevant synthetic information appeared on the screen. The issues addressed in both videos were: (i) private versus public interest at the city hall; (ii) links between the Expo organization and the mafia; (iii) the management of public appointments; (iv) the city's urban plan.

The video ad with the positive tone ran under the header "my ideas for Milan." The video ad with the negative tone ran under the header "is Ms. Moratti's Milan also your Milan?" The English translations of the messages read in the two videos are in the Appendix. Both videos ended with a common last slogan of endorsement: "Giuliano

Pisapia for mayor." Also in this case, after each video, respondents were asked to evaluate the message ("overall, how truthful does this electoral message seem to you?"). 
Participants in the (second and third) surveys were also exposed to the incumbent's campaign, which was fixed and administered in exactly the same way to both group A and group B. Also for this campaign, we used the same four tools: video with the candidate; campaign slogan; open letter to voters; video ad endorsed by the candidate. We acquired these items from Ms. Moratti's actual campaign. Details on their format and content are in the Appendix. For each tool, we randomized whether survey respondents were first exposed to the opponent's or to the incumbent's campaign message.

\subsection{Outcome Variables}

The fourth and last survey, administrated immediately after the election, collected the (self-reported) voting outcomes. Individual were asked whether they voted at the election, and (if yes) which candidate and party they voted for (choosing among a list of names for the candidates, and among a list of symbols for the parties). As the result of the first electoral round led to a runoff, individuals were also asked whether they expected to vote at the runoff, and if so for which of the two candidates. These answers provided the "in the field" component of our survey experiment, and represent our main outcomes of interest in the empirical analysis. Additionally, respondents were asked their motivations for the voting decisions (whether it was based on ideology or on the candidates' attributes), how confident they felt about their vote, and how negative or positive they perceived the incumbent's and the opponent's electoral campaigns.

Tables 3 and 4 show the average effects of our informational treatments on voting choices, respectively, in the first round and in the runoff, estimated by linear probability model. ${ }^{11}$ As already discussed, the first-round results capture (self-declared) actual choices, while second-round results capture voting intentions. In both cases, we concentrate on (actual or expected) turnout, the vote share of the opponent, and the vote share of the incumbent. For the first round, we also measure the vote share of the remaining (minor) candidates; for the second round, we measure the share of voters who were still undecided at the time of our last survey. Table 3 shows that neither positive nor negative campaigning influenced voting behaviors with respect to the control group, or when compared between each other. Table 4 shows equivalent results for the runoff. Here, the only

\footnotetext{
${ }^{11}$ Results are quantitatively equivalent with probit and logit models (available upon request).
} 
non-zero average effect is on the share of undecided voters, which increases for individuals who were exposed to the opponent's negative campaign. Overall, however, no convincing evidence exists of any significant impact of our treatments on voters' behavior.

\section{Empirical Results}

In the following, we discuss our empirical results in two steps. First, in Section 4.1, we investigate the differential response of male vs. female voters to positive campaigning, negative campaigning, or no campaign information. Second, we explore the potential mechanisms behind the disclosed gender differences. We are able to rule out gender identification with the candidates (see Section 4.2), as well as ideology or other observable attributes of the voters (see Section 4.3), as the main channels behind our results. We therefore conclude by discussing the possible interpretation of (residual) gender differences in the response to competitive persuasion in political campaigns (see Section 4.4).

\subsection{Effect of Campaign Information by Gender}

The survey experiment in the field described above provides an ideal environment to investigate how females and males react to political communication, because the share of female and male voters is almost equal and observable characteristics are orthogonal to the informational treatments within gender strata. Appendix Tables A1 and A2, which report balance tests as in Table 2, show that observable covariates are indeed balanced across treatment groups for both females and males, respectively. Most importantly, the nonresponse rate - which is determined after our treatments took place - is also balanced across treatment groups by gender. As a result, the randomization design allows us to estimate the causal impact of positive vs. negative campaigning for both men and women. We thus estimate the following linear probability model by OLS:

$Y_{i}=\alpha_{1} P O S_{i}+\alpha_{2} N E G_{i}+\beta_{1} P O S_{i} \times F E M A L E_{i}+\beta_{2} N E G_{i} \times F E M A L E_{i}+\delta F E M A L E_{i}+\varepsilon_{i}$,

where POS and NEG are dummies that identify the exposure to positive or negative campaign, respectively, FEMALE is a dummy identifying female voters, and standard 
errors are clustered by ZIP code to account for spatial correlation. ${ }^{12}$ This specification allows us to estimate the treatment effect of positive and negative campaign for males and females both with respect to the control group and between each other. ${ }^{13}$

Table 5 shows the results on first-round voting choices. Negative campaigning increases male turnout with respect to both the control group (at the $5 \%$ significance level) and positive campaigning ( $10 \%$ significance). In particular, when facing the opponent's negative campaign, males show up more at the polls by 8 percentage points, which amount to a persuasion rate of about 24\%. ${ }^{14}$ Negative campaigning has instead no effect on female turnout. Receiving any kind of campaign information has opposite effects on male and female turnout (H6): positive on the former and negative on the latter, although the effects in the two subpopulations are borderline insignificant at standard levels.

Gender differences are even more pronounced if we look at the candidates' vote shares. Females vote more for the opponent (by 8 percentage points) and less for the incumbent (by exactly the same 8 points) when they are exposed to the opponent's positive campaign. The persuasion rate of the positive campaign is about $21 \%$. The opposite happens for males, who vote less for the opponent (by 11 percentage points) and more for the incumbent (by 12.7 points) if exposed to the opponent's positive campaign. In this case, the (counterproductive) persuasion rate of the positive campaign on males is about $23 \%$. The effects of positive campaign are statistically significant for both males and females with respect to the control group, and for females with respect to negative campaign too. ${ }^{15}$

\footnotetext{
${ }^{12}$ Results are quantitatively equivalent with probit and logit models, even slightly more robust in terms of statistical significance (available upon request). We prefer to report results from the linear probability model to make the interpretation of the interaction coefficients more intuitive.

${ }^{13}$ Specifically, when we estimate our baseline equation (1), we also implement the following Wald tests. (H1) Treatment effect of positive vs. negative campaign for males: $\alpha_{1}-\alpha_{2}=0$. (H2) Treatment effect of positive vs. negative campaign for females: $\left(\alpha_{1}+\beta_{1}\right)-\left(\alpha_{2}+\beta_{2}\right)=0$. (H3) Differential treatment effect of positive vs. negative campaign between males and females: $\beta_{1}-\beta_{2}=0$. (H4) Treatment effect of any campaign vs. no campaign for males: $\alpha_{1}+\alpha_{2}=0$. (H5) Treatment effect of any campaign vs. no campaign for females: $\left(\alpha_{1}+\beta_{1}\right)+\left(\alpha_{2}+\beta_{2}\right)=0$. (H6) Differential treatment effect of any campaign vs. no campaign between males and females: $\beta_{1}+\beta_{2}=0$.

${ }^{14}$ Following DellaVigna and Kaplan (2007), we calculate the persuasion rate of our informational treatments as follows: $p=\frac{Y_{t}-Y_{c}}{e_{t}-e_{c}} \frac{1}{1-Y_{0}}$, where $Y_{t}$ and $Y_{c}$ are the shares of individuals adopting the behavior of interest (e.g, turnout) in the treated and control group, respectively; $e_{t}$ and $e_{c}$ are the shares of individuals receiving the message in the two groups (i.e., $e_{t}=1$ and $e_{c}=0$ in our case); and $Y_{0}$ is the share that would adopt the behavior of interest without the message (e.g., actual turnout in the population).

${ }^{15}$ Appendix Table A3 makes the comparison between positive and negative campaign more transparent by dropping the control group from the estimation sample.
} 
There are no significant effects on the cumulative vote shares of the other (minor) candidates. Overall, the above persuasion rates fit in the upper tail of the distribution of the effects unveiled so far in the literature on persuasion, where the maximum is around $30 \%$ according to the review by DellaVigna and Gentzkow (2010).

In Table 6, the same gender differences show up in the results on (expected) voting behavior in the runoff. ${ }^{16}$ Here, the opponent's positive campaign affects also the share of the undecided among women, which decreases by 9.5 percentage points with respect to negative campaign. Both in the first round and in the runoff, when men and women vote for a candidate, they tend to react in opposite ways to our treatments (H3). From the opponent's viewpoint, positive campaign is extremely fruitful in attracting female voters, but backfires with male voters. Indeed, males are more likely to vote for the incumbent when they are exposed to any campaign (H4), although the negative campaign attenuates this effect by recovering some votes for the opponent. This finding could be related to the tone of the incumbent's campaign, which, as inferred from our control group, was generally perceived to be negative. Hence, males seem to be attracted by negative campaigns.

Tables 7 and 8 examine the impact effect of each campaign tool, as measured by the replies to questions on the approval rate of the two candidates, asked after each tool was administered. Specifically, Table 7 uses the questions asked after the video interview ("do you agree with what the candidate says in the video?") and after the campaign slogan ("how much do you feel you can trust the candidate?"). Table 8 uses the questions asked after the open letter ("do you agree with the general sense of this letter?") and after the video ad ("how truthful does this electoral message seem to you?"). As the control group did not participate in the second and third survey, which provided our treatments, for these outcomes we can only evaluate the relative effect of positive vs. negative campaign.

By measuring the instantaneous reaction of respondents to the messages, the above variables resemble standard outcomes in existing lab or survey experiments. Results on gender differences are again striking: responses go systematically in opposite directions, and most of the time the difference is statistically significant at standard levels. In both the second and third survey, males are more in favor of the incumbent if they are exposed to the opponent's positive campaign, but this is never true for females, who actually tend

\footnotetext{
${ }^{16}$ See Appendix Table A4 for the direct comparison between positive vs. negative campaign.
} 
to trust less the incumbent if they are exposed to the opponent's positive video interview and campaign slogan.

Although the behavioral response to campaign communication is different between males and females, their perceptions about the tone of the campaign is similar. Table 9 shows that both males or females perceive the overall campaign (first column) and the opponent's campaign (second column) as more negative, if they are exposed to the (opponent's) negative informational treatment. Direct questions on perceptions may fail to capture the true impact of our treatments on voters' beliefs. Nevertheless, it is reassuring that these effects have the expected sign, and do not differ between males and females. Gender differences emerge again on the incumbent's campaign, however: those females who observed the opponent's positive campaign tend to perceive the incumbent as more negative, and the opposite occurs for males, although these effects are not statistically significant in the two subsamples. Table 9 also shows that our treatments have no effect on how confident voters are about their choice (third column) or on the motivation of their vote (fourth column).

\subsection{Potential Channel: Gender Identification}

A potential limitation in the interpretation of our findings is that the 2011 Milan election showed a mixed-gender race, between a female incumbent, Letizia Moratti, and a male opponent, Giuliano Pisapia. As a result, gender identification may drive the results (see Akerlof and Kranton, 2000): females may dislike negative advertising against a female candidate, whereas males may accept (or even like) the male opponent attacking the female incumbent. This mechanism would limit the external validity of our results to mixed-gender elections.

The emergence of a "natural" experiment, within the framework of the survey experiment, allows us to test for this potential channel in our sample. During the electoral campaign, the (female) incumbent staged a very negative and aggressive attack against the (male) opponent in a debate hosted by Sky TV. The attack consisted in allegations that the opponent, in his youth, had been involved in a car robbery together with friends who later became part of a terrorist organization. The allegation lately turned out to be false, but the negative attack had a huge echo in local and national news media, repre- 
senting a turning point of the campaign. The opponent was clearly shocked by the attack during the television show and refused to shake hands with the incumbent.

Interestingly, our third survey was still under way when the Sky TV show was aired (see Figure 1). As a result, some individuals had already participated in the survey, while others (14\% of the sample) had not. We therefore exploit the (exogenous) timing of the survey response, in order to evaluate the impact of a negative attack carried out by a female candidate against a male candidate, unlike in our survey experiment. Clearly, to implement this evaluation, we must restrict the attention to the outcomes measured in the third survey, because at the time of the fourth survey all voters had already come to know about the Sky TV episode.

We use the same outcomes analyzed in Table 8 and estimate whether female and male voters who replied after the Sky TV show have different evaluations on the quality of both the incumbent's and the opponent's campaign. We report the results in Table 10. In panel A, we estimate the OLS model:

$$
Y_{i}=\alpha_{1} A F T E R_{i}+\beta_{1} A F T E R_{i} \times F E M A L E_{i}+\delta F E M A L E_{i}+\varepsilon_{i}
$$

where the dummy $A F T E R_{i}$ captures whether the individual responded to the third survey after the Sky TV show or not. Clearly, these are intention-to-treat effects, because we are unable to know whether those individuals who replied after the show actually heard about the episode. The dependent variables are the answers to the questions on whether respondents agree with the candidates' open letter and video ad. Female voters - againtend to punish the candidate who went negative (even though this time it is a woman): they agree less with the letter and trust less the video by the incumbent after the negative attack. On the contrary, male voters do not punish the female incumbent. If anything, they tend to rally in her favor even if she went negative against a male candidate.

We are aware that individuals responding earlier or later to the survey may be different along some unobservable dimension. To control for this, in panel B of Table 10, we augment equation (2) with a spline third-order polynomial in the distance from the time of the event:

$$
Y_{i}=\alpha_{1} A F T E R_{i}+\beta_{1} A F T E R_{i} \times F E M A L E_{i}+\delta F E M A L E_{i}+f\left(D I S T A N C E_{i}\right)+\varepsilon_{i}
$$

where DISTANCE $E_{i}$ is measured in minutes. This amounts to a regression discontinuity design in the distance from the Sky TV show. All outcomes convey the same conclusion 
as the OLS estimations. Even in a small neighborhood of the event (that is, comparing individuals who answered the survey just before or just after the show), females and males respond differently to the negative attack carried out by the incumbent, thereby suggesting that no gender identification is at work in our sample.

\subsection{Potential Channel: Ideology or Other Observables}

We now turn to another potential channel that might explain our results. Do males and females respond differently to our informational treatments because of intrinsically different attitudes, or simply because gender is systematically associated with other dimensions, such as ideology or education, which might explain the above results? The existing literature suggests that female voters tend to prefer more public spending than male voters (Cavalcanti and Tavares, 2011; Funk and Gathmann, 2010) and have become more left-leaning (Edlund and Pande, 2002). ${ }^{17}$ Indeed, as shown in Table 11, male and female respondents differ along several observable characteristics, such as age, marital status, left-wing orientation, and interest in politics. These gender differences in observables, however, do not represent a threat to the validity of our estimates, as they are not systematically different across treatment groups (see Table 12) and we have already shown that covariates are balanced across treatment groups within gender strata.

It is however possible that the interpretation of our results might be affected by observable differences. Are females convinced by the opponent's positive campaign because of the tone of the messages, or because they are more left-leaning? To shed more light on these potential channels, we proceed in two steps. First, we show that the main confounding channel correlated with gender - namely, ideology - does not drive our findings. Also in our sample, females voters are more likely to self-position themselves on the left of the political spectrum. However, this does not interact with our findings, since left-wing and right-wing voters do not show differential responses to the informational treatments. Table 13 (first round) and Table 14 (runoff) show that, indeed, left-wing and right-wing voters align with the candidate of their respective coalition, but none of our informational treatments has a differential effect on voters with different ideological orientations.

\footnotetext{
${ }^{17}$ Men and women seem to differ also as policy makers: female politicians support a larger allocation of public funds to programs such as education and childcare (Chattopadhyay and Duflo, 2004; Rehavi, 2007; Clots-Figueras, 2011), perhaps due to their higher social preferences (Croson and Gneezy, 2009).
} 
Finally, we include all observable characteristics and their full set of interactions with the treatment indicators in an augmented specification aimed at capturing the net effect of gender, after controlling for everything else. This specification is quite demanding from a statistical viewpoint, because it increases the number of cells where we are trying to estimate the treatment effects, and statistical significance is considerably reduced. Actually, also from a substantial viewpoint, some regressors such as marital status might be an example of over-controlling, because gender might be intrinsically associated with different preferences in this respect. Nevertheless, we report these specifications in Table 15 (first round) and in Table 16 (runoff) as the most conservative test on gender differences. Notably, the direction of the results discussed in the previous sections is unchanged even when we control for a full set of interactions. The differential response to positive vs. negative campaign by gender is only partially explained by differences in ideological preferences, political information, interest in politics, or demographic characteristics. The bottom line is that a residual underlying gender difference lies behind our findings.

\subsection{Discussion: Residual Gender Differences}

The empirical results in the previous sections suggest the existence of a pure gender effect behind the differential response to political advertising. Male and female voters are convinced by different communication strategies. But why? The existing economic and neuro-psychological literature may provide some interesting insights.

A recent (mostly experimental) economic literature - see Croson and Gneezy, 2009, and Bertrand, 2010, for a review - has shown that females feel less comfortable than males in competitive environments. Females tend to "shy away from competition," while males may choose to compete too much (see Niederle and Vesterlund, 2007). In particular, females' performance has been shown to worsen during a competition-be it solving mazes (Gneezy, Niederle and Rustichini, 2003), running (Gneezy and Rustichini, 2004), or playing tennis (Paserman, 2010). Consistently, women are less likely to choose competitive environments (Dohmen and Falk, 2011) than males. ${ }^{18}$

Our empirical results are in line with this evidence. When exposed to a more com-

\footnotetext{
${ }^{18}$ To what extent this different gender behavior is due to nature (Kimura, 1999) or nurture (Gneezy et al., 2009; and Booth and Nolen, 2012) is still open to debate.
} 
petitive persuasion strategy (negative ads), our female voters align against the sender of the messages, whereas when exposed to a more inclusive (and less competitive) campaign, consisting of the opponent's positive ads, they are induced to vote for him. The opposite occurs instead for male voters. Unlike in this literature, however, our experiment does not expose the voters to direct competition. In other words, they do not perform a task in order to obtain a (monetary) reward. They are rather exposed to a more or less aggressive persuasion strategy, and females choose the more inclusive one.

Our evidence is also consistent with another strand of literature, which analyzes gender differences in attitudes toward violence, where the phenomenon does not directly affect the respondents (see Smith, 1984; Sapiro and Johnston Conover, 1993). For instance, in a controlled experiment using war scenarios, Brooks and Valentino (2011) show that women are less likely to support war than men, and that female support for war increases when missions have humanitarian objectives and are approved by the United Nations. Hence, our evidence is consistent with females having a lower taste for (any) competitive or aggressive behavior, rather than their shying away from competition being driven for instance by higher risk aversion (see Niederle and Vesterlund, 2007).

The existence of gender differences has largely been recognized by a neuropsychological literature (Baron-Cohen, Knickmeyer, and Belmonte, 2005). In response to direct psychological stress, which can be elicited for instance by requiring individuals to perform mental arithmetic tasks or a free speech in front of an audience (see Kudielka and Kirschbaum, 2005, for a review), important sex differences emerge. Through brain scanners, males have been shown to have greater reactivity than females to stressful situations. ${ }^{19}$ Gender difference also emerge when individuals are exposed to indirect external stimuli. A series of studies (see Cahill, 2003; Cahill et al., 2000; Cahill et al., 2004; Canli et al., 2002; Hamann and Canli, 2004) identifies a sex-related hemispheric lateralization of the amygdala activity in response to an emotionally arousing event, such as watching a movie. ${ }^{20}$

\footnotetext{
${ }^{19}$ Reactivity is usually measured by more cerebral blood flow in the right prefrontal cortex, where negative emotion and vigilance systems are located, by less blood flow in the left orbitofrontal cortex, which is associated with positive emotions and hedonic goals (see Wang et al., 2007), and by an increase in cortisol. Produced by the adrenal gland, cortisol is a hormone that mobilizes resources to provide energy.

${ }^{20}$ Since males tend to activate the right portion of the amygdala, which is biased toward global aspects, while females the left portion, which specializes in finer details, sex differences emerge in processing the same stimulus. This difference may carry on to how individuals imagine the future, since memories have been shown to represent the building blocks for imagining future scenarios (see Schacter and Addis, 2007).
} 
Our empirical results are in line also with this literature. More arousing events, such a persuasion strategy based on negative advertising, seem to stimulate more actions among males - who respond by increasing turnout and by voting against the proponent of the positive campaign - than among females, who find instead more appealing an inclusive persuasion strategy.

\section{Conclusion}

Competitive persuasion has become increasingly more important, and thereby more sophisticated, in business and politics. Multiple senders of advertising messages compete for the attention of a large mass of receivers - being them buyers or voters - and try to influence their decisions. The diffusion of social networks and the ability of processing the huge amount of information collected in large datasets have allowed sellers and politicians to identify with strong precision their favorite targets: undecided, potential buyers, and swing voters. Since the ads can now be placed in front of the right receiver, shouldn't also the message be tailored to persuade him or her?

Our experimental evidence from the 2011 electoral campaign in Milan strongly suggests that the gender of the receiver does indeed matter. In our randomized campaign, negative ads brought men to the polls, but not women. On the other hand, a positive electoral campaign by the opponent increased his vote share, and reduced the incumbent's votes, among female voters. The opposite occurred instead among male voters.

Additional empirical tests suggest that this gender difference is neither driven by gender identification, nor by other confounding effects, such as females being more left leaning. This deep difference in voting behavior may perhaps be attributed to different tastes for competition (Niederle and Vesterlund, 2007) or to different neuro-psychological responses to external stimuli (Kudielka and Kirschbaum, 2005), such as electoral video ads. Addi-

tional research is needed to analyze possible gender differences in environments in which individuals are not directly subject to-but rather spectator of - aggressive competition. This may help to establish whether males and females do indeed have a different taste for competition per se. 


\section{References}

[1] Akerlof, G.A., and R.E. Kranton (2000), "Economics and Identity," Quarterly Journal of Economics, 115(3): 715-753.

[2] Ansolabehere, S., S. Iyengar, A. Simon, and N. Valentino (1994), "Does Attack Advertising Demobilize the Electorate?" American Political Science Review, 88(4): 829-838.

[3] Ansolabehere, S., and S. Iyengar (1995), Going Negative: How Political Advertisements Shrink and Polarize the Electorate, New York: The Free Press.

[4] Arceneaux, K., and D.W. Nickerson (2010), "Comparing Negative and Positive Campaign Messages," American Politics Research, 38(1): 54-83.

[5] Bagues, M., and B. Esteve-Volart (2012), "Are Women Pawns in the Political Game? Evidence from Elections to the Spanish Senate," Journal of Public Economics, 96: 387-399.

[6] Baltrunaite, A., P. Bello, A. Casarico, and P. Profeta (2012), "Gender Quotas and the Quality of Politicians," CESifo Working Paper 3734.

[7] Baron-Cohen, S., R.C. Knickmeyer, and M.K. Belmonte (2005), "Sex Differences in the Brain: Implications for Explaining Autism," Science, 310(4): 819-823.

[8] Bertrand, M. (2010), "New Perspectives on Gender", in D. Card and O. Ashenfelter (eds), Handbook of Labor Economics, Vol 4, Part B, Amsterdam: Elsevier Ltd.

[9] Bertrand M., D.S. Karlan, S. Mullainathan, E. Shafir, and J. Zinman (2010), "What's Advertising Content Worth? Evidence from a Consumer Credit Marketing Field Experiment," Quarterly Journal of Economics, 125: 263-305.

[10] Booth, A.L., and P. Nolen (2012), "Choosing to compete: How different are girls and boys?" Journal of Economic Behavior and Organization, 81(2): 542-555.

[11] Brooks, D.J., and B.A. Valentino (2011), "A War on One's Own: Understanding the Gender Gap in Support of the War," Public Opinion Quarterly, 75(2): 270-286.

[12] Brooks, D.J., and J.G. Geer (2007), "Beyond Negativity: The Effects of Incivility on the Electorate," American Journal of Political Science, 51(1): 1-16.

[13] Cahill, L. (2003), "Sex - and hemisphere - related influences on the neurobiology of emotionally influenced memory," Progress in Neuro-Psychopharmacology and Biological Psychiatry, 27: $1235-1241$.

[14] Cahill, L., M. Uncapher, L. Kilpatrick, M.T. Alkire, and J. Turner (2004), "Sex-Related Hemispheric Lateralization of Amygdala Function in Emotionally Influenced Memory: An FMRI Investigation," Learning and Memory, 11: 261-266.

[15] Canli, T., J.E. Desmond, Z. Zhao, and J.D.E. Gabrieli (2002), "Sex differences in the neural basis of emotional memories". PNAS, 99(16): 10789-10794. 
[16] Cavalcanti, T.V., and J. Tavares (2011), "Women Prefer Larger Governments: Growth, Structural Transformation, And Government Size," Economic Inquiry, 49(1): 155-171.

[17] Chattopadhyay, R., and E. Duflo (2004), "Women as Policy Makers: Evidence from a Randomized Policy Experiment in India," Econometrica, 72(5): 1409-1443.

[18] Clinton, J.D., and J.S. Lapinski (2004), "Targeted Advertising and Voter Turnout: An Experimental Study of the 2000 Presidential Election," Journal of Politics, 66(1): 69-96.

[19] Clots-Figueras, I. (2011), "Women in Politics," Journal of Public Economics, 95: 664-690.

[20] Croson, R., and U. Gneezy (2009), "Gender Differences in Preferences," Journal of Economic Literature, 47(2): 448-474.

[21] DellaVigna, S., and E. Kaplan (2007), "The Fox News Effect: Media Bias and Voting," Quarterly Journal of Economics, 122(3): 1187-234.

[22] DellaVigna, S., and M. Gentzkow (2010), "Persuasion: Empirical Evidence," Annual Review of Economics, 2: 643-69.

[23] DellaVigna, S., J.A. List, and U. Malmendier (2012), "Testing for Altruism and Social Pressure in Charitable Giving," Quarterly Journal of Economics, 127(1): 1-56.

[24] Dewan, T., M. Humphreys, and D. Rubenson (2010), "The Impact of Leaders and the Messages They Convey," LSE manuscript.

[25] Dohmen, T. and A. Falk (2011), "Performance Pay and Multidimensional Sorting: Productivity, Preferences, and Gender," American Economic Review, 101(2): 556-590.

[26] Edlund, L., and R. Pande (2002), "Why Have Women Become Left-Wing? The Political Gender Gap And The Decline In Marriage," Quarterly Journal of Economics, 117: 917-961.

[27] Finkel, S.E., and J.G. Geer (1998), "A Spot Check: Casting Doubt on the Demobilizing Effect of Attack Advertising," American Journal of Political Science, 42(2): 573-595.

[28] Freedman, P., and K. Goldstein (1999), "Measuring Media Exposure and the Effects of Negative Campaign Ads," American Journal of Political Science, 43(4): 1189-1208.

[29] Fridkin, K.L., and P.J. Kenney (2011), "Variability in Citizens' Reactions to Different Types of Negative Campaigns," American Journal of Political Science, 55(2): 307-325.

[30] Funk, P., and C. Gathmann (2010), "How do Electoral Systems Affect Fiscal Policy? Evidence from State and Local Governments, 1890 to 2005," CESifo Working Paper 2958.

[31] Gagliarducci, S., and M.D. Paserman (2012), "Gender Interactions within Hierarchies: Evidence from the Political Arena," Review of Economic Studies, 79(3): 1021-1052.

[32] Gentzkow, M., and E. Kamenica (2011), "Competition in Persuasion," NBER Working Paper 17436. 
[33] Gentzkow M., J.M. Shapiro, and M. Sinkinson (2011), "The Effect of Newspaper Entry and Exit on Electoral Politics," American Economic Review, 101(7): 2980-3018.

[34] Gerber, A.S., J.G. Gimpel, D.P. Green, and D. Shaw (2011), "How Large and Long-lasting Are the Persuasive Effects of Televised Campaign Ads? Results from a Randomized Field Experiment," American Political Science Review, 105: 135-150.

[35] Gerber, A.S., and D.P. Green (2000), "The Effects of Canvassing, Telephone Calls, and Direct Mail on Voter Turnout: A Field Experiment," American Political Science Review, 94: 653-63.

[36] Gerber, A.S., D.P. Green, and R. Shachar (2003), "Voting May Be Habit-Forming: Evidence from a Randomized Field Experiment," American Journal of Political Science, 47: 540-50.

[37] Glaeser, E.L., G. Ponzetto, and J.M. Shapiro (2005), "Strategic Extremism: Why Republicans and Democrats Divide on Religious Values," Quarterly Journal of Economics, 120(4): $1283-1330$.

[38] Gneezy, U. and A. Rustichini (2004), "Gender and Competition at a Young Age," American Economic Review, 94(2): 377-381.

[39] Gneezy, U., K.L. Leonard, and J.A. List (2009), "Gender Differences in Competition: Evidence from a Matrilineal and a Patriarchal Society," Econometrica, 77(5): 1637-1664.

[40] Gneezy, U., M. Niederle, and A. Rustichini (2003), "Performance in Competitive Environments: Gender Differences," Quarterly Journal of Economics, 118(3): 1049-1074.

[41] Goldstein, K., and P. Freedman (2002), "Campaign Advertising and Voter Turnout: New Evidence for a Simulation Effect," Journal of Politics, 64(3): 721-740.

[42] Green, D.P., and A.S. Gerber (2004), Get Out the Vote: How to Increase Voter Turnout, Washington, D.C.: Brookings Institution Press.

[43] Hamann, S., and T. Canli (2004), "Individual differences in emotion processing," Current Opinion in Neurobiology, 14: 233-238.

[44] Kahn, K.F., and P.J. Kenney (1999), "Do Negative Campaigns Mobilize or Suppress Turnout? Clarifying the Relationship between Negativity and Participation," American Political Science Review, 93(4): 877-889.

[45] Kendall, C., T. Nannicini, and F. Trebbi (2013), "How Do Voters Respond to Information? Evidence from a Randomized Campaign," NBER Working Paper 18986.

[46] Kimura, D. (1999), Sex and Cognition, Cambridge (MA): MIT Press.

[47] Kudielka, B.M., and C. Kirschbaum (2005), "Sex Differences in HPA Axis Responses to Stress: A Review," Biological Psychology, 69: 113-132.

[48] Lau, R., L. Sigelman, and I.B. Rovner (2007), "The Effects of Negative Political Campaigns: A Meta-Analytic Reassessment," Journal of Politics, 69(4): 1176-1209. 
[49] Murphy, K.M., and A. Shleifer (2004), "Persuasion in Politics," American Economic Review $P \& P, 94(2):$ 435-439.

[50] Nickerson, D.W. (2008), "Is Voting Contagious? Evidence from Two Field Experiments," American Political Science Review, 102: 49-57.

[51] Niederle, M., and L. Vesterlund (2007), "Do Women Shy Away From Competition? Do Men Compete Too Much?" Quarterly Journal of Economics, 122(3): 1067-1101.

[52] Paserman, D. (2010), "Gender Differences in Performance in Competitive Environments? Evidence from Professional Tennis Players," Boston University Working Paper 2010-047.

[53] Prakash, V. (1992), "Sex Roles and Advertising Preferences," Journal of Advertising Research, May/June: 43-52.

[54] Rehavi, M. (2007), "Sex and Politics: Do Female Legislators Affect State Spending?" UBC manuscript.

[55] Sapiro, V., and P.J. Conover (1993), "Gender, Feminist Consciousness, and War," American Journal of Political Science, 37(4): 1079-1099.

[56] Schacter, D.L., and D.R. Addis (2007), "The cognitive neuroscience of constructive memory: remembering the past and imagining the future," Philosophical Transitions, 362: 773-786.

[57] Smith, T.W. (1984), "The Polls: Gender and Attitudes Toward Violence," Public Opinion Quarterly, 48: 384-396.

[58] Vilela, A.M., and M.R. Nelson (2006), "Values: Better than Sex Segmentation Strategy for Cause-Related Marketing Messages," paper presented at the Annual Meeting of the International Communication Association, Dresden.

[59] Wang, J., M. Korczykowski, H. Rao, Y. Fan, J. Pluta, R.C. Gur, B.S. McEwen, and J.A. Detre (2007), "Gender difference in neural response to psychological stress," Social Cognitive and Affective Neuroscience, 2(3): 227-239.

[60] Wattenberg, M.P., and C.L. Brians (1999), "Negative Campaign Advertising: Demobilizer or Mobilizer?" American Political Science Review, 93(4): 891-899. 


\section{Figures and Tables}

\section{Figure 1 - Timing of the Experimental Design}

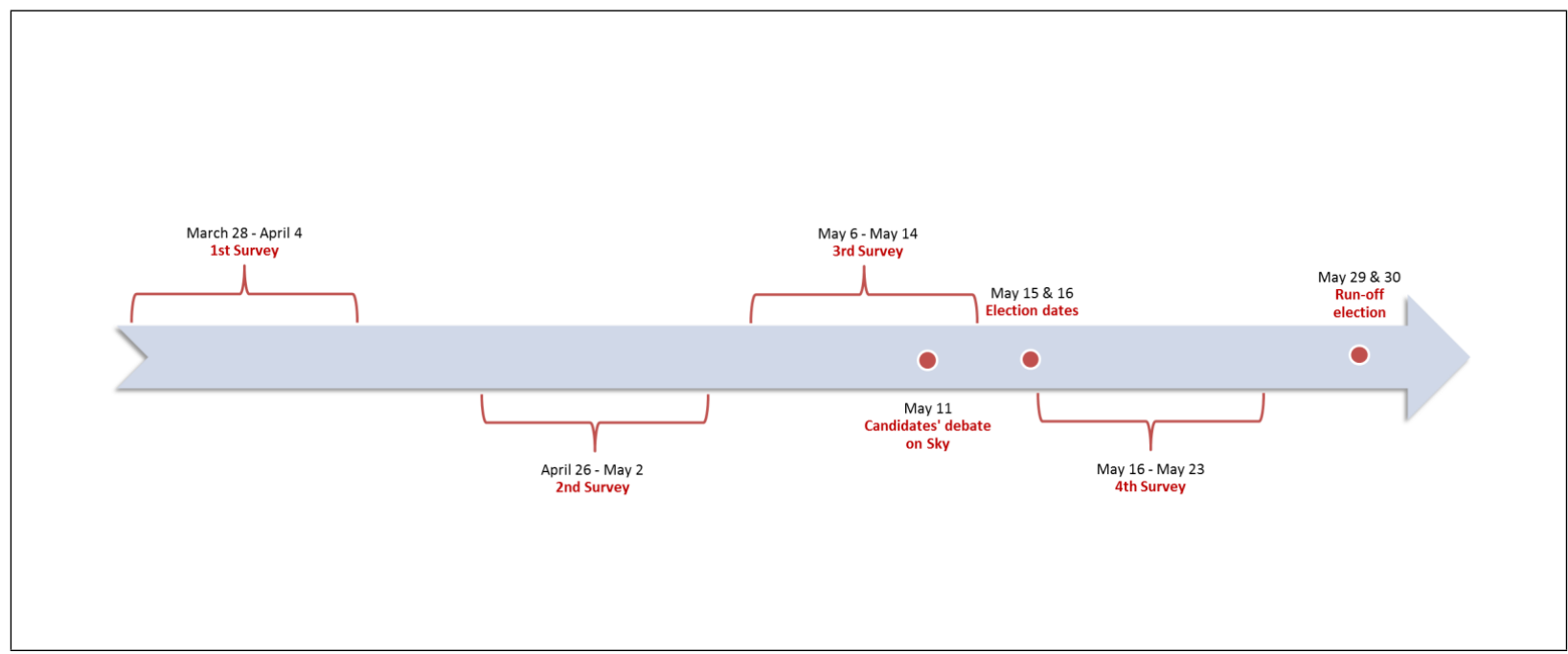

Notes. All dates refer to 2011. The timeline reports the starting and ending dates of the four online surveys; the date of the candidates' debate on Sky TV; and the dates of the elections (first round and runoff). The first (pre-randomization) survey profiled the eligible voters in the sample. The second survey administered the first two informational treatments: video interviews with the candidates; campaign slogans. The third survey administered the last two informational treatments: open letters to voters; video ads endorsed by the candidates. The fourth (post-election) survey elicited voting behaviors. 

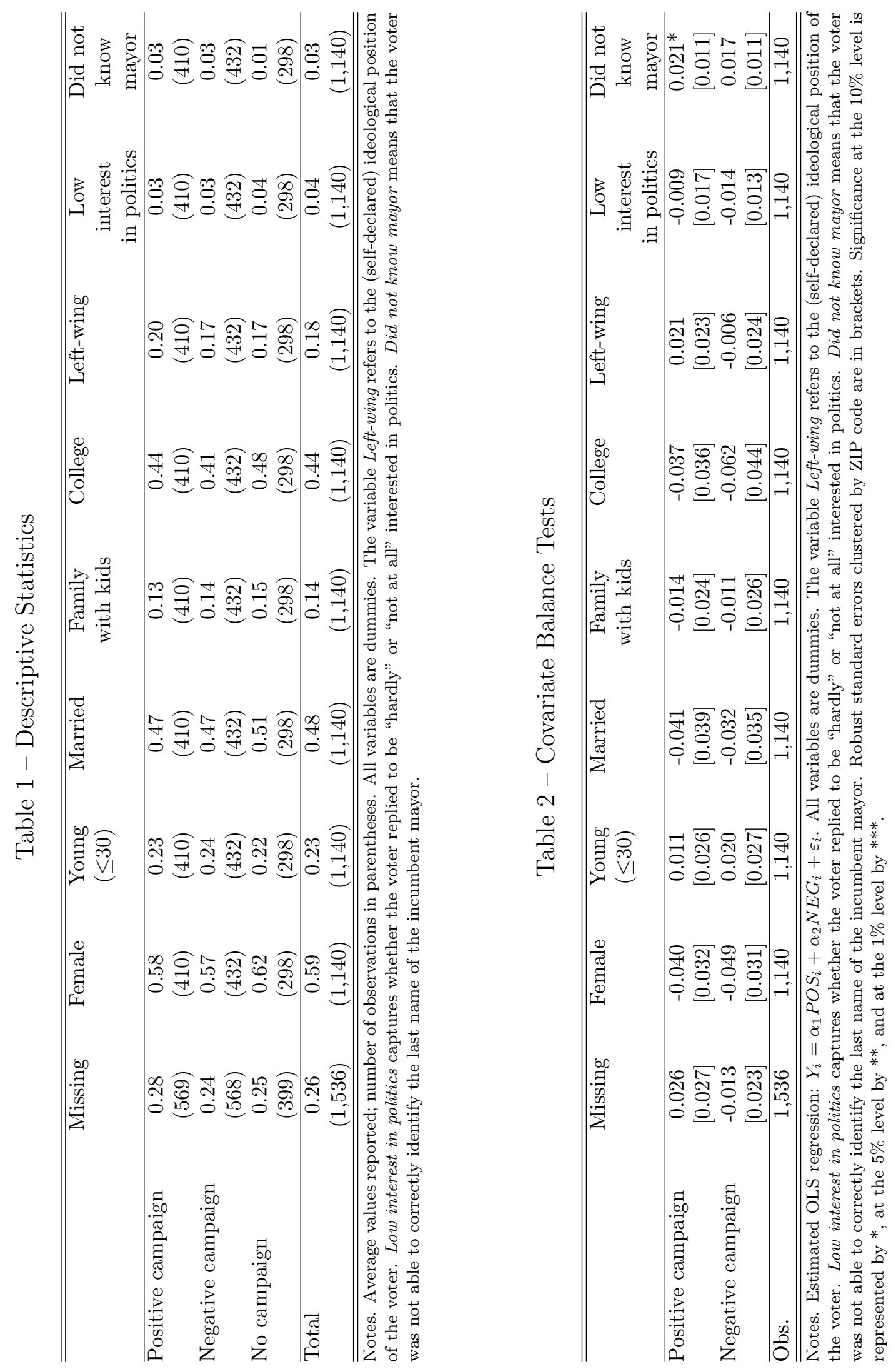
Table 3 - Average Treatment Effects, First Round

\begin{tabular}{lcccc}
\hline \hline & $\begin{array}{c}\text { Turnout } \\
\text { rate }\end{array}$ & $\begin{array}{c}\text { Opponent's } \\
\text { vote share }\end{array}$ & $\begin{array}{c}\text { Incumbent's } \\
\text { vote share }\end{array}$ & $\begin{array}{c}\text { Others' } \\
\text { vote share }\end{array}$ \\
\hline Positive campaign $\left(\alpha_{1}\right)$ & -0.018 & -0.002 & 0.004 & -0.002 \\
Negative campaign $\left(\alpha_{2}\right)$ & {$[0.023]$} & {$[0.042]$} & {$[0.039]$} & {$[0.036]$} \\
& 0.014 & -0.038 & 0.037 & 0.001 \\
P-value H1: $\alpha_{1}-\alpha_{2}=0$ & {$[0.022]$} & {$[0.041]$} & {$[0.036]$} & {$[0.030]$} \\
P-value H2: $\alpha_{1}+\alpha_{2}=0$ & 0.162 & 0.321 & 0.402 & 0.922 \\
\hline Obs. & 0.916 & 0.597 & 0.526 & 0.985 \\
\hline \hline
\end{tabular}

Notes. Estimated OLS regression: $Y_{i}=\alpha_{1} P O S_{i}+\alpha_{2} N E G_{i}+\varepsilon_{i}$. (H1) Treatment effect of positive vs. negative campaign: $\alpha_{1}-\alpha_{2}=0$. (H2) Treatment effect of any campaign vs. no campaign: $\alpha_{1}+\alpha_{2}=0$. Robust standard errors are in brackets. Significance at the $10 \%$ level is represented by $*$, at the $5 \%$ level by $* *$, and at the $1 \%$ level by $* * *$.

Table 4 - Average Treatment Effects, Runoff

\begin{tabular}{|c|c|c|c|c|}
\hline & $\begin{array}{c}\text { Expected } \\
\text { turnout }\end{array}$ & $\begin{array}{c}\text { Vote for } \\
\text { opponent }\end{array}$ & $\begin{array}{c}\text { Vote for } \\
\text { incumbent }\end{array}$ & Undecided \\
\hline \multirow{2}{*}{ Positive campaign $\left(\alpha_{1}\right)$} & 0.010 & 0.012 & 0.020 & -0.032 \\
\hline & {$[0.026]$} & {$[0.036]$} & {$[0.035]$} & {$[0.032]$} \\
\hline \multirow[t]{2}{*}{ Negative campaign $\left(\alpha_{2}\right)$} & 0.013 & 0.021 & 0.044 & $-0.065^{* *}$ \\
\hline & {$[0.025]$} & {$[0.032]$} & {$[0.034]$} & {$[0.027]$} \\
\hline$\overline{P \text {-value } H 1: \alpha_{1}-\alpha_{2}=0}$ & 0.860 & 0.811 & 0.505 & 0.150 \\
\hline$P$-value H2: $\alpha_{1}+\alpha_{2}=0$ & 0.630 & 0.558 & 0.283 & $0.080^{*}$ \\
\hline Obs. & 1,119 & 1,034 & 1,034 & 1,034 \\
\hline
\end{tabular}


Table 5 - Differential Effects of Campaign Information by Gender, First Round

\begin{tabular}{|c|c|c|c|c|}
\hline & $\begin{array}{l}\text { Turnout } \\
\text { rate }\end{array}$ & $\begin{array}{l}\text { Opponent's } \\
\text { vote share }\end{array}$ & $\begin{array}{l}\text { Incumbent's } \\
\text { vote share }\end{array}$ & $\begin{array}{c}\text { Others' } \\
\text { vote share }\end{array}$ \\
\hline \multirow[t]{2}{*}{ Positive campaign $\left(\alpha_{1}\right)$} & 0.031 & $-0.110^{*}$ & $0.127^{* *}$ & -0.018 \\
\hline & [0.043] & [0.059] & {$[0.054]$} & [0.063] \\
\hline \multirow{2}{*}{ Negative campaign $\left(\alpha_{2}\right)$} & $0.082^{* *}$ & -0.075 & 0.100 & -0.025 \\
\hline & [0.037] & [0.069] & [0.061] & {$[0.054]$} \\
\hline \multirow{2}{*}{ Positive campaign $\times$ Female $\left(\beta_{1}\right)$} & -0.080 & $0.190^{* *}$ & $-0.207^{* * *}$ & 0.018 \\
\hline & [0.051] & [0.080] & [0.075] & [0.070] \\
\hline \multirow{2}{*}{ Negative campaign $\times$ Female $\left(\beta_{2}\right)$} & $-0.114^{* *}$ & 0.065 & -0.101 & 0.036 \\
\hline & {$[0.049]$} & {$[0.083]$} & [0.077] & [0.065] \\
\hline \multirow{2}{*}{ Female } & 0.061 & 0.004 & 0.067 & -0.071 \\
\hline & {$[0.040]$} & {$[0.071]$} & {$[0.057]$} & {$[0.052]$} \\
\hline P-value H1: $\alpha_{1}-\alpha_{2}=0$ & $0.092^{*}$ & 0.435 & 0.619 & 0.876 \\
\hline P-value H2: $\alpha_{1}+\beta_{1}-\left(\alpha_{2}+\beta_{2}\right)=0$ & 0.556 & $0.062^{*}$ & $0.074^{*}$ & 0.776 \\
\hline$P$-value $H 3: \beta_{1}-\beta_{2}=0$ & 0.365 & $0.035^{* *}$ & $0.076^{*}$ & 0.785 \\
\hline$P$-value $H_{4}: \alpha_{1}+\alpha_{2}=0$ & 0.137 & 0.132 & $0.033^{* *}$ & 0.694 \\
\hline P-value H5: $\alpha_{1}+\beta_{1}+\alpha_{2}+\beta_{2}=0$ & 0.102 & 0.460 & 0.342 & 0.870 \\
\hline P-value H6: $\beta_{1}+\beta_{2}=0$ & $0.043^{* *}$ & 0.104 & $0.034^{* *}$ & 0.656 \\
\hline Obs. & 1,140 & 912 & 912 & 912 \\
\hline \multicolumn{5}{|c|}{$\begin{array}{l}\text { Notes. Estimated OLS regression: } Y_{i}=\alpha_{1} P O S_{i}+\alpha_{2} N E G_{i}+\beta_{1} P O S_{i} \times F E M A L E_{i}+\beta_{2} N E G_{i} \times F E M A L E_{i}+\delta F E M A L E_{i}+ \\
\varepsilon_{i} \text {. (H1) Treatment effect of positive vs. negative campaign for males: } \alpha_{1}-\alpha_{2}=0 . \text { (H2) Treatment effect of positive } \\
\text { vs. negative campaign for females: }\left(\alpha_{1}+\beta_{1}\right)-\left(\alpha_{2}+\beta_{2}\right)=0 \text {. (H3) Differential treatment effect of positive vs. negative } \\
\text { campaign between males and females: } \beta_{1}-\beta_{2}=0 \text {. (H4) Treatment effect of any campaign vs. no campaign for males: } \\
\alpha_{1}+\alpha_{2}=0 \text {. (H5) Treatment effect of any campaign vs. no campaign for females: }\left(\alpha_{1}+\beta_{1}\right)+\left(\alpha_{2}+\beta_{2}\right)=0 \text {. (H6) Differential } \\
\text { treatment effect of any campaign vs. no campaign between males and females: } \beta_{1}+\beta_{2}=0 \text {. Robust standard errors are in } \\
\text { brackets. Significance at the } 10 \% \text { level is represented by } * \text {, at the } 5 \% \text { level by **, and at the } 1 \% \text { level by } * * * \text {. }\end{array}$} \\
\hline
\end{tabular}




\section{Table 6 - Differential Effects of Campaign Information by Gender, Runoff}

\begin{tabular}{|c|c|c|c|c|}
\hline & $\begin{array}{c}\text { Expected } \\
\text { turnout }\end{array}$ & $\begin{array}{c}\text { Vote for } \\
\text { opponent }\end{array}$ & $\begin{array}{c}\text { Vote for } \\
\text { incumbent }\end{array}$ & Undecided \\
\hline \multirow[t]{2}{*}{ Positive campaign $\left(\alpha_{1}\right)$} & 0.022 & -0.085 & $0.184^{* * *}$ & $-0.099 * *$ \\
\hline & {$[0.046]$} & {$[0.058]$} & {$[0.057]$} & {$[0.043]$} \\
\hline \multirow[t]{2}{*}{ Negative campaign $\left(\alpha_{2}\right)$} & $0.067^{*}$ & -0.051 & $0.129 * *$ & $-0.078^{*}$ \\
\hline & {$[0.035]$} & {$[0.063]$} & {$[0.062]$} & {$[0.043]$} \\
\hline \multirow[t]{2}{*}{ Positive campaign $\times$ Female $\left(\beta_{1}\right)$} & -0.017 & $0.163^{*}$ & $-0.272^{* * *}$ & $0.109^{*}$ \\
\hline & {$[0.046]$} & {$[0.081]$} & {$[0.082]$} & {$[0.060]$} \\
\hline \multirow[t]{2}{*}{ Negative campaign $\times$ Female $\left(\beta_{2}\right)$} & $-0.089 * *$ & 0.124 & $-0.139^{*}$ & 0.015 \\
\hline & {$[0.042]$} & {$[0.086]$} & {$[0.080]$} & {$[0.053]$} \\
\hline \multirow[t]{2}{*}{ Female } & 0.051 & -0.042 & 0.096 & -0.054 \\
\hline & {$[0.035]$} & {$[0.070]$} & {$[0.068]$} & {$[0.051]$} \\
\hline$\overline{P \text {-value } H 1:} \alpha_{1}-\alpha_{2}=0$ & 0.141 & 0.467 & 0.300 & 0.569 \\
\hline P-value H2: $\alpha_{1}+\beta_{1}-\left(\alpha_{2}+\beta_{2}\right)=0$ & 0.256 & 0.921 & $0.061^{*}$ & $0.032^{* *}$ \\
\hline$P$-value $H 3: \beta_{1}-\beta_{2}=0$ & $0.059^{*}$ & 0.473 & $0.028^{* *}$ & $0.087^{*}$ \\
\hline$P$-value $H_{4}: \alpha_{1}+\alpha_{2}=0$ & 0.251 & 0.228 & $0.006^{* * *}$ & $0.028 * *$ \\
\hline P-value H5: $\alpha_{1}+\beta_{1}+\alpha_{2}+\beta_{2}=0$ & 0.716 & $0.081^{*}$ & 0.247 & 0.450 \\
\hline P-value $H 6: \beta_{1}+\beta_{2}=0$ & 0.190 & $0.078^{*}$ & $0.010^{* * *}$ & 0.225 \\
\hline Obs. & 1,119 & 1,034 & 1,034 & 1,034 \\
\hline
\end{tabular}


Table 7 - Differential Impact Effects of Campaign Tools ( $2^{\text {nd }}$ Survey)

\begin{tabular}{lcccc}
\hline \hline & $\begin{array}{c}\text { Agree with } \\
\text { opponent's } \\
\text { video }\end{array}$ & $\begin{array}{c}\text { Agree with } \\
\text { incumbent's } \\
\text { video }\end{array}$ & $\begin{array}{c}\text { Trust } \\
\text { opponent }\end{array}$ & $\begin{array}{c}\text { Trust } \\
\text { incumbent }\end{array}$ \\
\hline Positive campaign $\left(\alpha_{1}\right)$ & -0.067 & $0.147^{* *}$ & -0.060 & $0.157^{* * *}$ \\
Positive campaign $\times$ Female $\left(\beta_{1}\right)$ & {$[0.051]$} & {$[0.060]$} & {$[0.049]$} & {$[0.056]$} \\
Female & 0.108 & $-0.196^{* *}$ & 0.092 & $-0.244^{* * *}$ \\
P-value H1: $\alpha_{1}+\beta_{1}=0$ & {$[0.070]$} & {$[0.078]$} & {$[0.072]$} & {$[0.065]$} \\
Obs. & -0.013 & 0.076 & -0.024 & $0.088^{*}$ \\
\hline \hline
\end{tabular}

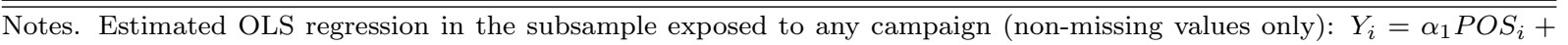
$\beta_{1} P O S_{i} \times F E M A L E_{i}+\delta F E M A L E_{i}+\varepsilon_{i}$. (H1) Treatment effect of positive vs. negative campaign for females: $\alpha_{1}+\beta_{1}=0$. First two columns refer to questions asked after the video interview with each candidate ("do you agree with what the candidate says in the video?"); last two columns refer to questions asked after the campaign slogan of each candidate ("how much do you feel you can trust the candidate?"). Robust standard errors are in brackets. Significance at the $10 \%$ level is represented by $*$, at the $5 \%$ level by ${ }^{* *}$, and at the $1 \%$ level by $* * *$.

Table 8 - Differential Impact Effects of Campaign Tools ( $3^{\text {rd }}$ Survey)

\begin{tabular}{|c|c|c|c|c|}
\hline & $\begin{array}{l}\text { Agree with } \\
\text { opponent's } \\
\text { letter }\end{array}$ & $\begin{array}{l}\text { Agree with } \\
\text { incumbent's } \\
\text { letter }\end{array}$ & $\begin{array}{c}\text { Trust } \\
\text { opponent's } \\
\text { video }\end{array}$ & $\begin{array}{c}\text { Trust } \\
\text { incumbent's } \\
\text { video }\end{array}$ \\
\hline \multirow{2}{*}{ Positive campaign $\left(\alpha_{1}\right)$} & 0.055 & $0.156^{* *}$ & -0.061 & $0.143^{* *}$ \\
\hline & {$[0.060]$} & {$[0.059]$} & {$[0.058]$} & {$[0.057]$} \\
\hline \multirow{2}{*}{ Positive campaign $\times$ Female $\left(\beta_{1}\right)$} & -0.008 & $-0.200^{* *}$ & 0.103 & $-0.181^{* *}$ \\
\hline & {$[0.068]$} & {$[0.078]$} & {$[0.076]$} & {$[0.078]$} \\
\hline \multirow[t]{2}{*}{ Female } & 0.005 & 0.020 & 0.016 & 0.023 \\
\hline & {$[0.049]$} & {$[0.049]$} & {$[0.058]$} & {$[0.053]$} \\
\hline P-value H1: $\alpha_{1}+\beta_{1}=0$ & 0.269 & 0.380 & 0.359 & 0.424 \\
\hline Obs. & 762 & 762 & 762 & 762 \\
\hline \multicolumn{5}{|c|}{$\begin{array}{l}\text { Notes. Estimated OLS regression in the subsample exposed to any campaign (non-missing values only): } Y_{i}=\alpha_{1} P O S_{i}+ \\
\beta_{1} P O S_{i} \times F E M A L E_{i}+\delta F E M A L E_{i}+\varepsilon_{i} \text {. (H1) Treatment effect of positive vs. negative campaign for females: } \alpha_{1}+\beta_{1}=0 \text {. } \\
\text { First two columns refer to questions asked after each candidate's open letter to voters ("do you agree with the general sense } \\
\text { of this letter?"); last two columns refer to questions asked after the video ad endorsed by each candidate ("how truthful does } \\
\text { this electoral message seem to you?"). Robust standard errors are in brackets. Significance at the } 10 \% \text { level is represented } \\
\text { by }{ }^{*} \text {, at the } 5 \% \text { level by }{ }^{* *} \text {, and at the } 1 \% \text { level by }{ }^{* * *} \text {. }\end{array}$} \\
\hline
\end{tabular}


Table 9 - Differential Effects on Perceptions

\begin{tabular}{lccccc}
\hline \hline & $\begin{array}{c}\text { Perceive } \\
\text { campaign } \\
\text { as harsh }\end{array}$ & $\begin{array}{c}\text { Perceive } \\
\text { opponent } \\
\text { as negative }\end{array}$ & $\begin{array}{c}\text { Perceive } \\
\text { incumbent } \\
\text { as negative }\end{array}$ & $\begin{array}{c}\text { Confident } \\
\text { about vote } \\
\text { choice }\end{array}$ & $\begin{array}{c}\text { Voted based on } \\
\text { candidates' } \\
\text { attributes }\end{array}$ \\
\hline Positive campaign $\left(\alpha_{1}\right)$ & $-0.085^{*}$ & $-0.089^{*}$ & -0.067 & -0.038 & 0.021 \\
& {$[0.045]$} & {$[0.050]$} & {$[0.047]$} & {$[0.053]$} & {$[0.049]$} \\
Positive campaign $\times$ Female $\left(\beta_{1}\right)$ & 0.007 & 0.032 & $0.130^{* *}$ & 0.091 & 0.000 \\
& {$[0.065]$} & {$[0.072]$} & {$[0.048]$} & {$[0.061]$} & {$[0.084]$} \\
Female & -0.050 & -0.081 & -0.035 & -0.041 & 0.039 \\
P-value $H 1: \alpha_{1}+\beta_{1}=0$ & {$[0.048]$} & {$[0.049]$} & {$[0.044]$} & {$[0.052]$} & {$[0.044]$} \\
Obs. & $0.087^{*}$ & 0.217 & 0.172 & 0.319 & 0.727 \\
\hline \hline
\end{tabular}

Notes. Estimated OLS regression: $Y_{i}=\alpha_{1} P O S_{i}+\beta_{1} P O S_{i} \times F E M A L E_{i}+\delta F E M A L E_{i}+\varepsilon_{i}$. (H1) Treatment effect of positive vs. negative campaign for females: $\alpha_{1}+\beta_{1}=0$. Robust standard errors are in brackets. Significance at the $10 \%$ level is represented by ${ }^{*}$, at the $5 \%$ level by ${ }^{* *}$, and at the $1 \%$ level by ${ }^{* * *}$.

Table 10 - Differential Effects of Sky TV Show on $3^{\text {rd }}$ Survey Outcomes

\begin{tabular}{|c|c|c|c|c|}
\hline & $\begin{array}{l}\text { Agree with } \\
\text { opponent's } \\
\text { letter }\end{array}$ & $\begin{array}{c}\text { Agree with } \\
\text { incumbent's } \\
\text { letter }\end{array}$ & $\begin{array}{c}\text { Trust } \\
\text { opponent's } \\
\text { video }\end{array}$ & $\begin{array}{c}\text { Trust } \\
\text { incumbent's } \\
\text { video }\end{array}$ \\
\hline & \multicolumn{4}{|c|}{ A. OLS specifications } \\
\hline \multirow{2}{*}{ After Sky $\left(\alpha_{1}\right)$} & -0.113 & 0.113 & -0.043 & 0.092 \\
\hline & {$[0.069]$} & {$[0.078]$} & {$[0.086]$} & {$[0.079]$} \\
\hline \multirow[t]{2}{*}{ After Sky $\times$ Female $\left(\beta_{1}\right)$} & $0.189 * *$ & $-0.207^{* *}$ & -0.021 & $-0.213^{* *}$ \\
\hline & {$[0.087]$} & {$[0.079]$} & [0.109] & {$[0.083]$} \\
\hline \multirow[t]{2}{*}{ Female } & -0.024 & -0.045 & 0.067 & -0.033 \\
\hline & {$[0.042]$} & {$[0.038]$} & {$[0.040]$} & {$[0.034]$} \\
\hline \multirow[t]{2}{*}{ P-value $H 1: \alpha_{1}+\beta_{1}=0$} & 0.166 & $0.091^{*}$ & 0.273 & $0.041^{* *}$ \\
\hline & \multicolumn{4}{|c|}{ B. RD specifications } \\
\hline \multirow[t]{2}{*}{ After Sky $\left(\alpha_{1}\right)$} & -0.142 & 0.139 & -0.121 & 0.071 \\
\hline & [0.089] & {$[0.088]$} & {$[0.117]$} & [0.093] \\
\hline \multirow[t]{2}{*}{ After Sky $\times$ Female $\left(\beta_{1}\right)$} & $0.182^{* *}$ & $-0.201^{* *}$ & -0.040 & $-0.219^{* *}$ \\
\hline & {$[0.086]$} & {$[0.077]$} & [0.109] & {$[0.083]$} \\
\hline \multirow[t]{2}{*}{ Female } & -0.021 & -0.050 & $0.069^{*}$ & -0.041 \\
\hline & {$[0.043]$} & {$[0.039]$} & {$[0.041]$} & {$[0.035]$} \\
\hline P-value H1: $\alpha_{1}+\beta_{1}=0$ & 0.631 & 0.409 & 0.113 & 0.116 \\
\hline Obs. & 762 & 762 & 762 & 762 \\
\hline
\end{tabular}



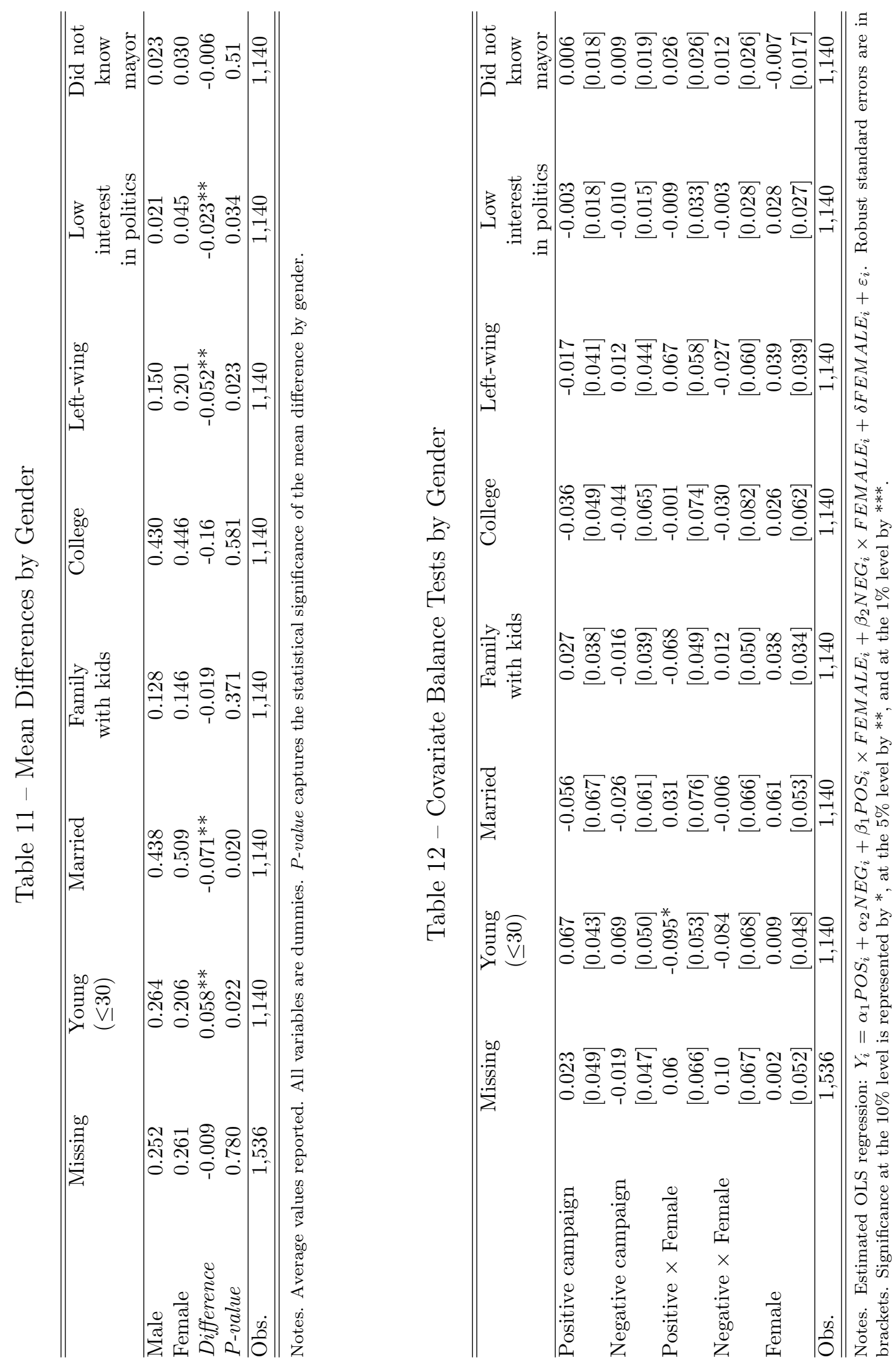
Table 13 - Differential Effects of Campaign Information by Ideology, First Round

\begin{tabular}{|c|c|c|c|c|}
\hline & $\begin{array}{l}\text { Turnout } \\
\text { rate }\end{array}$ & $\begin{array}{l}\text { Opponent's } \\
\text { vote share }\end{array}$ & $\begin{array}{l}\text { Incumbent's } \\
\text { vote share }\end{array}$ & $\begin{array}{c}\text { Others' } \\
\text { vote share }\end{array}$ \\
\hline \multirow{2}{*}{ Positive campaign $\left(\alpha_{1}\right)$} & -0.012 & 0.000 & 0.010 & -0.010 \\
\hline & {$[0.028]$} & {$[0.047]$} & [0.048] & {$[0.042]$} \\
\hline \multirow{2}{*}{ Negative campaign $\left(\alpha_{2}\right)$} & 0.017 & -0.030 & 0.033 & -0.004 \\
\hline & {$[0.024]$} & {$[0.043]$} & {$[0.046]$} & {$[0.039]$} \\
\hline \multirow{2}{*}{ Positive campaign $\times$ Left-wing $\left(\beta_{1}\right)$} & -0.029 & -0.054 & 0.002 & 0.052 \\
\hline & {$[0.066]$} & [0.097] & {$[0.096]$} & {$[0.065]$} \\
\hline \multirow{2}{*}{ Negative campaign $\times$ Left-wing $\left(\beta_{2}\right)$} & -0.016 & -0.043 & 0.019 & 0.024 \\
\hline & {$[0.063]$} & {$[0.090]$} & {$[0.079]$} & {$[0.095]$} \\
\hline \multirow[t]{2}{*}{ Left-wing } & 0.010 & $0.336^{* * *}$ & $-0.244^{* * *}$ & -0.092 \\
\hline & {$[0.050]$} & {$[0.072]$} & {$[0.073]$} & {$[0.061]$} \\
\hline$\overline{P \text {-value } H 1:} \alpha_{1}-\alpha_{2}=0$ & 0.254 & 0.432 & 0.622 & 0.828 \\
\hline$P$-value H2: $\alpha_{1}+\beta_{1}-\left(\alpha_{2}+\beta_{2}\right)=0$ & 0.395 & 0.862 & 0.522 & 0.754 \\
\hline P-value H3: $\beta_{1}-\beta_{2}=0$ & 0.819 & 0.923 & 0.837 & 0.712 \\
\hline$P$-value $H_{4}: \alpha_{1}+\alpha_{2}=0$ & 0.930 & 0.721 & 0.597 & 0.853 \\
\hline$P$-value H5: $\alpha_{1}+\beta_{1}+\alpha_{2}+\beta_{2}=0$ & 0.684 & 0.336 & 0.538 & 0.587 \\
\hline P-value H6: $\beta_{1}+\beta_{2}=0$ & 0.700 & 0.526 & 0.897 & 0.603 \\
\hline Obs. & 1,140 & 912 & 912 & 912 \\
\hline \multicolumn{5}{|c|}{ 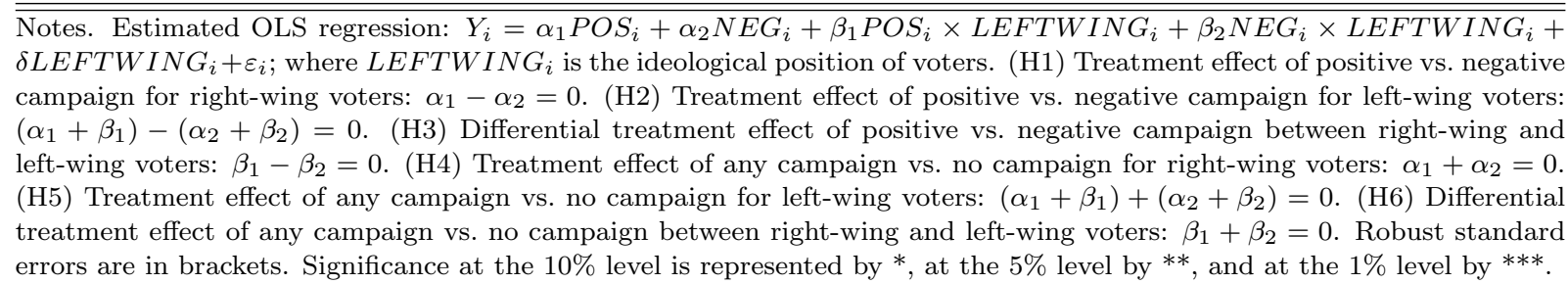 } \\
\hline
\end{tabular}


Table 14 - Differential Effects of Campaign Information by Ideology, Runoff

\begin{tabular}{|c|c|c|c|c|}
\hline & $\begin{array}{c}\text { Expected } \\
\text { turnout }\end{array}$ & $\begin{array}{c}\text { Vote for } \\
\text { opponent }\end{array}$ & $\begin{array}{l}\text { Vote for } \\
\text { incumbent }\end{array}$ & Undecided \\
\hline \multirow[t]{2}{*}{ Positive campaign $\left(\alpha_{1}\right)$} & 0.019 & -0.014 & 0.035 & -0.021 \\
\hline & {$[0.032]$} & {$[0.044]$} & {$[0.040]$} & {$[0.037]$} \\
\hline \multirow{2}{*}{ Negative campaign $\left(\alpha_{2}\right)$} & 0.014 & 0.018 & 0.044 & $-0.062^{*}$ \\
\hline & {$[0.030]$} & {$[0.038]$} & {$[0.040]$} & {$[0.032]$} \\
\hline \multirow[t]{2}{*}{ Positive campaign $\times$ Left-wing $\left(\beta_{1}\right)$} & -0.055 & 0.107 & -0.055 & -0.053 \\
\hline & {$[0.058]$} & {$[0.108]$} & {$[0.074]$} & {$[0.075]$} \\
\hline \multirow{2}{*}{ Negative campaign $\times$ Left-wing $\left(\beta_{2}\right)$} & -0.003 & 0.025 & -0.003 & -0.022 \\
\hline & {$[0.046]$} & {$[0.092]$} & {$[0.067]$} & {$[0.072]$} \\
\hline \multirow{2}{*}{ Left-wing } & 0.056 & $0.271^{* * *}$ & $-0.212^{* * *}$ & -0.059 \\
\hline & {$[0.039]$} & {$[0.087]$} & {$[0.055]$} & {$[0.067]$} \\
\hline P-value H1: $\alpha_{1}-\alpha_{2}=0$ & 0.788 & 0.458 & 0.825 & 0.115 \\
\hline P-value H2: $\alpha_{1}+\beta_{1}-\left(\alpha_{2}+\beta_{2}\right)=0$ & 0.136 & 0.525 & 0.284 & 0.831 \\
\hline$P$-value H3: $\beta_{1}-\beta_{2}=0$ & 0.138 & 0.374 & 0.477 & 0.582 \\
\hline$P$-value $H_{4}: \alpha_{1}+\alpha_{2}=0$ & 0.568 & 0.959 & 0.246 & 0.209 \\
\hline P-value H5: $\alpha_{1}+\beta_{1}+\alpha_{2}+\beta_{2}=0$ & 0.739 & 0.337 & 0.836 & 0.175 \\
\hline P-value H6: $\beta_{1}+\beta_{2}=0$ & 0.561 & 0.463 & 0.637 & 0.588 \\
\hline Obs. & 1,119 & 1,034 & 1,034 & 1,034 \\
\hline \multicolumn{5}{|c|}{$\begin{array}{l}\text { Notes. Estimated OLS regression: } Y_{i}=\alpha_{1} P O S_{i}+\alpha_{2} N E G_{i}+\beta_{1} P O S_{i} \times L E F T W I N G_{i}+\beta_{2} N E G_{i} \times L E F T W I N G_{i}+ \\
\delta L E F T W I N G_{i}+\varepsilon_{i} \text {; where } L E F T W I N G_{i} \text { is the ideological position of voters. (H1) Treatment effect of positive vs. negative } \\
\text { campaign for right-wing voters: } \alpha_{1}-\alpha_{2}=0 \text {. (H2) Treatment effect of positive vs. negative campaign for left-wing voters: } \\
\left(\alpha_{1}+\beta_{1}\right)-\left(\alpha_{2}+\beta_{2}\right)=0 \text {. (H3) Differential treatment effect of positive vs. negative campaign between right-wing and } \\
\text { left-wing voters: } \beta_{1}-\beta_{2}=0 \text {. (H4) Treatment effect of any campaign vs. no campaign for right-wing voters: } \alpha_{1}+\alpha_{2}=0 \text {. } \\
\text { (H5) Treatment effect of any campaign vs. no campaign for left-wing voters: }\left(\alpha_{1}+\beta_{1}\right)+\left(\alpha_{2}+\beta_{2}\right)=0 \text {. (H6) Differential } \\
\text { treatment effect of any campaign vs. no campaign between right-wing and left-wing voters: } \beta_{1}+\beta_{2}=0 \text {. Robust standard } \\
\text { errors are in brackets. Significance at the } 10 \% \text { level is represented by } * \text {, at the } 5 \% \text { level by } * * \text {, and at the } 1 \% \text { level by } * * * \text {. }\end{array}$} \\
\hline
\end{tabular}


Table 15 - Augmented Specifications with Full Set of Interactions, First Round

\begin{tabular}{|c|c|c|c|c|}
\hline & $\begin{array}{c}\text { Turnout } \\
\text { rate }\end{array}$ & $\begin{array}{l}\text { Opponent's } \\
\text { vote share }\end{array}$ & $\begin{array}{l}\text { Incumbent's } \\
\text { vote share }\end{array}$ & $\begin{array}{c}\text { Others' } \\
\text { vote share }\end{array}$ \\
\hline \multirow[t]{2}{*}{ Positive campaign $\left(\alpha_{1}\right)$} & 0.027 & -0.037 & 0.130 & -0.093 \\
\hline & {$[0.051]$} & {$[0.067]$} & {$[0.078]$} & {$[0.075]$} \\
\hline \multirow{2}{*}{ Negative campaign $\left(\alpha_{2}\right)$} & 0.061 & -0.066 & $0.140^{*}$ & -0.074 \\
\hline & [0.038] & {$[0.063]$} & {$[0.076]$} & [0.072] \\
\hline \multirow{2}{*}{ Positive campaign $\times$ Female $\left(\beta_{1}\right)$} & -0.076 & $0.141^{*}$ & $-0.172^{* *}$ & 0.031 \\
\hline & {$[0.050]$} & {$[0.075]$} & [0.068] & [0.068] \\
\hline \multirow{2}{*}{ Negative campaign $\times$ Female $\left(\beta_{2}\right)$} & $-0.107^{* *}$ & 0.056 & -0.098 & 0.042 \\
\hline & {$[0.048]$} & [0.083] & {$[0.074]$} & [0.063] \\
\hline \multirow{2}{*}{ Female } & 0.058 & 0.008 & 0.058 & -0.066 \\
\hline & {$[0.040]$} & {$[0.070]$} & {$[0.055]$} & {$[0.050]$} \\
\hline$P$-value H1: $\alpha_{1}-\alpha_{2}=0$ & 0.356 & 0.634 & 0.890 & 0.668 \\
\hline P-value H2: $\alpha_{1}+\beta_{1}-\left(\alpha_{2}+\beta_{2}\right)=0$ & 0.927 & $0.087^{*}$ & 0.194 & 0.472 \\
\hline$P$-value H3: $\beta_{1}-\beta_{2}=0$ & 0.435 & 0.136 & 0.202 & 0.869 \\
\hline$P$-value $H_{4}: \alpha_{1}+\alpha_{2}=0$ & 0.290 & 0.373 & $0.056^{*}$ & 0.238 \\
\hline P-value H5: $\alpha_{1}+\beta_{1}+\alpha_{2}+\beta_{2}=0$ & $0.093^{*}$ & 0.423 & 0.997 & 0.333 \\
\hline P-value H6: $\beta_{1}+\beta_{2}=0$ & $0.051^{*}$ & 0.187 & $0.044^{* *}$ & 0.532 \\
\hline Obs. & 1,140 & 912 & 912 & 912 \\
\hline
\end{tabular}


Table 16 - Augmented Specifications with Full Set of Interactions, Runoff

\begin{tabular}{|c|c|c|c|c|}
\hline & $\begin{array}{l}\text { Expected } \\
\text { turnout }\end{array}$ & $\begin{array}{c}\text { Vote for } \\
\text { opponent }\end{array}$ & $\begin{array}{c}\text { Vote for } \\
\text { incumbent }\end{array}$ & Undecided \\
\hline \multirow[t]{2}{*}{ Positive campaign $\left(\alpha_{1}\right)$} & 0.041 & -0.107 & $0.221^{* * *}$ & $-0.114^{*}$ \\
\hline & [0.048] & [0.083] & {$[0.067]$} & {$[0.056]$} \\
\hline \multirow{2}{*}{ Negative campaign $\left(\alpha_{2}\right)$} & $0.070^{*}$ & -0.122 & $0.178^{* *}$ & -0.056 \\
\hline & [0.039] & {$[0.086]$} & {$[0.069]$} & {$[0.058]$} \\
\hline \multirow{2}{*}{ Positive campaign $\times$ Female $\left(\beta_{1}\right)$} & -0.014 & 0.120 & $-0.240^{* * *}$ & $0.120^{*}$ \\
\hline & {$[0.046]$} & {$[0.079]$} & {$[0.081]$} & [0.064] \\
\hline \multirow{2}{*}{ Negative campaign $\times$ Female $\left(\beta_{2}\right)$} & $-0.086^{* *}$ & 0.126 & $-0.139^{*}$ & 0.013 \\
\hline & {$[0.038]$} & {$[0.088]$} & [0.078] & {$[0.055]$} \\
\hline \multirow{2}{*}{ Female } & 0.050 & -0.041 & 0.093 & -0.052 \\
\hline & {$[0.033]$} & {$[0.072]$} & {$[0.067]$} & {$[0.053]$} \\
\hline$P$-value H1: $\alpha_{1}-\alpha_{2}=0$ & 0.370 & 0.789 & 0.566 & 0.209 \\
\hline P-value H2: $\alpha_{1}+\beta_{1}-\left(\alpha_{2}+\beta_{2}\right)=0$ & 0.226 & 0.885 & 0.351 & 0.273 \\
\hline$P$-value H3: $\beta_{1}-\beta_{2}=0$ & $0.058^{*}$ & 0.901 & $0.072^{*}$ & $0.070^{*}$ \\
\hline$P$-value $H_{4}: \alpha_{1}+\alpha_{2}=0$ & 0.181 & 0.156 & $0.001^{* *}$ & 0.115 \\
\hline P-value H5: $\alpha_{1}+\beta_{1}+\alpha_{2}+\beta_{2}=0$ & 0.851 & 0.883 & 0.873 & 0.699 \\
\hline P-value H6: $\beta_{1}+\beta_{2}=0$ & 0.198 & 0.132 & $0.016^{* *}$ & 0.212 \\
\hline$\overline{\text { Obs. }}$ & 1,119 & 1,034 & 1,034 & 1,034 \\
\hline
\end{tabular}




\section{Appendix I: Informational Treatments}

In the following sections, we report the English translation of our informational treatments. For complete materials (including original videos realized by professionals, online survey screenshots, etc.) please refer to the website: www.people.usi.ch/galassov/projects.html.

\section{A1 Opponent's (Randomized) Campaign \\ Second Survey: Video Interview with the Candidate}

The video interview with the opponent characterized by a positive tone is available online at the following link: http://www.youtube.com/embed/kW-cxPistYM. The English translation of the text reads as follows.

Interviewer: "How does Giuliano Pisapia plan to solve these problems and increase the quality of life of Milan's citizens?"

Opponent: "I have various ideas. We need to make public transportation an actual alternative to private transport, in particular to cars. We should give everyone the possibility to get around using bicycles. This can be done by extending the bike sharing service which cannot be limited only to the city center but should be available also in suburbs. We need to give people the possibility to use bikes as means of transport across the whole city, in the center and in the suburbs. We need new proposals to reduce traffic throughout the city and eliminate it from the city center. I believe that a congestion charge that makes everyone pay a small amount would enhance citizens' well-being. Plus, it would reduce the use of private cars alleviating traffic and pollution. In addition, the revenues from this charge - which needs to be paid by everyone but that will not greatly affect people's budgets - should be invested in public transport. This is the only way to solve problems such as traffic and pollution. Milan should have once again many green spaces and parks; this would greatly benefit not only children, but also adults and elderly. These green spaces can make a positive difference in the lives of our citizens."

The video interview with the opponent characterized by a negative tone is available online at the following link: http://www.youtube.com/embed/243QcAeA4C8. The English translation of the text reads as follows. 
Interviewer: "What are the main mistakes made by the Moratti administration in the past five years?"

Opponent: "The mayor proposed to raise the fare for public transportation even though, as citizens know very well, it is totally inefficient. In these years public transport has been increasingly more off schedule and citizens have had to wait more for buses and trolley cars than in the past. Plus, the speed of transportation has declined continuously. In fact, Milan now ranks 20th in Europe for speed of public transportation with an average speed of $13.5 \mathrm{Km} / \mathrm{hr}$ well below the European average of $20 \mathrm{Km} / \mathrm{hr}$. The Ecopass system is complete failure, in fact, the councillor that proposed it has been fired. It failed in every respect since it did not reduce traffic (except marginally in the center) and it did not improve the quality of the air we breathe. In Milan, the European critical level of Particulate Matters in the air has been crossed in 35 out of the first 38 days of the year, reaching the European annual limit. This proves that nothing has been done to alleviate traffic and to improve the quality of the air we breathe. Letizia Moratti not only didn't do anything effective to solve problems such as traffic and pollution, she also did not do anything to create more green spaces in Milan. The worst part is that she wasted a huge present that Maestro Abbado made to our city: 90,000 trees that certainly would have helped make Milan a greener city."

\section{Second Survey: Electoral Campaign Slogan}

Figure A1 and Figure A2 show the positive and negative slogans for the opponent's electoral campaign, respectively. The English translation of the positive slogan reads: "Pisapia for Mayor $=$ Less Traffic, More Parks. Change in Milan is possible." The English translation of the negative slogan reads: "5 years of Moratti = More Traffic, Less Parks. Change in Milan is possible."

\section{Third Survey: Open Letter to Voters}

The text of the open letter sent to the eligible voters with a positive tone is the following.

"Can a mayor contribute to the happiness of his citizens? I believe he can. Moreover, I am convinced that the primary duty of who governs in name of the general interest is to increase the wellbeing of his fellow citizens. Together with over a thousand volunteers of 
the Workshops for the City, I have defined four main goals:

1. I want to breath with you new air, finally clean.

2. I want to live in a city in which work is considered a source of dignity, freedom, and a fundamental value.

3. I want less cars in the city center, more public transportation, a stop a few meters from everyone's house also in the suburbs, less traffic, and the possibility to move quickly throughout the city also using bicycles.

4. I want to support those who dedicate their lives to culture; help it thrive sustaining creativity and free initiatives.

I commit to work for these goals. Milan deserves to become once again one of the capitals of Europe."

The text of the open letter sent to the eligible voters with a negative tone is the following.

"Can a mayor contribute to the happiness of his citizens? I believe he can. Moreover, I am convinced that the primary duty of who governs in name of the general interest is to increase the wellbeing of his fellow citizens. In Mrs. Moratti's Milan this did not happen.

She was indifferent to the city's problems and rarely present in the city council; therefore, she has proved to be unfit to serve our city.

1. City council. She only attended $5 \%$ of ballots, a record high level of absenteeism.

2. City's neighborhoods. Her indifference to the city's needs is obvious: the suburbs are completely abandoned.

3. Little attention was given to transportation and environment, particulate matters in the air are at the highest level since 2007 , and $20 \%$ of the city's shops pay protection money to the Mafia.

4. Only now - during the electoral campaign - Letizia Moratti is creating a few bikeways and is spending millions of Euros to disseminate throughout the city huge pictures that portray her surrounded by the citizens of Milan. 
Milan does not deserve other five years of Moratti administration. Change in Milan is possible."

\section{Third Survey: Video Ad Endorsed by the Candidate}

The video ad endorsed by the opponent and characterized by a positive tone is available online at the following link: http://www.youtube.com/embed/909RgdaC6Mg. The English translation of the text reads as follows.

"The 15th and 16th of May the citizens of Milan will vote to elect their Mayor. Giuliano Pisapia will challenge the incumbent Mayor. What does he plan to do for Milan? To make Milan closer to the needs of citizens, Giuliano Pisapia believes that public service rather than business interests should be a priority [video highlight appearing on the screen: 'Close to Citizens' Needs']. To truly fight organized crime, Giuliano Pisapia proposes an antiMafia commission that should oversee the works for Expo [video highlight: 'Anti-Mafia Commission']. To increase the city's efficiency, Giuliano Pisapia proposes to reward merit and to boost the skills of public employees and managers [video highlight: 'Merit and Competence']. To enhance transparency, Giuliano Pisapia believes that the town planning bill should be discussed with civil society and in the city council [video highlight: 'More Transparency']."

The video ad endorsed by the opponent and characterized by a negative tone is available online at the following link: http://www.youtube.com/embed/JcG0d6uZ-kk. The English translation of the text reads as follows.

"[Video highlight appearing on the screen: '15/16 of May'], Letizia Moratti runs again for mayor of Milan. Before choosing who to vote, ask yourself whether the Milan she has in mind is also your Milan. [Video highlight: '6th of October 2006'], Letizia Moratti undersells optic fibers. Private investors make a profit of $600 \%$, the city looses 50 million Euros [video highlight: '+ $600 \%$ to private investors'; '- 50 million Euros to the citizens of Milan']. [Video highlight: '12th of March 2009'], Letizia Moratti eliminates the anti-Mafia commission that was supposed to oversee the works for Expo [video highlight: "infiltrations of the Mafia"]. [Video highlight: '24th of May 2009'], investigation on public appointments, the Court of Auditors condemns Letizia Moratti and asks her to refund the city of Milan [video highlight: 'illegal public appointments]. [Video highlight: '4th of February 2011'], 
the town planning bill passed by Letizia Moratti tries to amend the one million Euro infringement of building regulations of her son Gabriele [video highlight: 'Bat-House']. Is this your Milan?"

\section{A2 Incumbent's (Non-Randomized) Campaign}

For our experiment, we also simulated the "entire" political campaign of the incumbent, Letizia Moratti, using the same tools of the opponent's campaign, and we then administered this (non-randomized) campaign to all groups during the second and third survey.

\section{Second Survey: Video Interview with the Candidate}

The video (available online at the link: http://www.youtube.com/embed/AHnjRoawu_Q) runs under the header "we want to complete our good work" and broadcasts a public speech by Letizia Moratti, as mayor of Milan, launching her electoral campaign in Piazza San Babila (city center). Surrounded by supporters holding flags and balloons, she promises to complete the projects that were started during her first mandate, with new subway lines being a top priority. The text of the video interview with the incumbent is the following.

"In all these years the center-right administration has always governed well. I have found balanced budgets thanks to mayors Albertini, Formentini, and all those who preceded me. Thanks to this, I have had the possibility to continue to invest. We have invested 3.9 billion Euros in public infrastructures. This allowed us to extend the subway lines: the number 2 line up to Assago has already been inaugurated and the number 3 up to Comasina has also already been inaugurated. We have also already put aside - they are already registered in our budgets - all the funds necessary to complete the new subway lines 4 and 5 before the Expo."

\section{Second Survey: Electoral Campaign Slogan}

The electoral campaign slogan following the video reads: "We are working to make Milan an even better place to live in. Letizia Moratti for Mayor." 


\section{Third Survey: Open Letter to Voters}

The header of the incumbent's open letter is "Milan is the city I love." It describes the philosophy that Mrs. Moratti wished to continue to adopt in her second term: to aim high (as with the Expo), but also to take care of the citizens' everyday needs. The text of the letter is the following.

"Milan is the city I love: it is the city in which I was born and raised. It thought me kindness, discretion, and diligence. In my life I have had to deal with situations in which I had great responsibilities. However, nothing is comparable to the emotions I felt when working for my city as Mayor of Milan. In these five years we have aimed at great accomplishments but at the same we took care of the small necessities of our citizens everyday lives.

- We aimed high competing and winning the contest for Expo 2015 which will make Milan capital of the world.

- We took care of small necessities rising security controls in the city's outskirts, investing in street lighting, creating new kindergarten facilities, reaching out to a larger number of elderly, and planting new trees.

I would like to complete the projects we have started in the past five years and make Milan a better place to live in. I will do this with anyone who wants to give the home of all Milanese people more strength, openness and beauty."

\section{Video Ad Endorsed by the Candidate}

The video ad endorsed by the incumbent is available at: http://youtu.be/F917BIexZc8. The English translation of the text reads as follows. The video plays under the header "Letizia Moratti: This is my Milan." "Our Milan says 'YES' to more homes for Italians, 'NO' to gypsy camps. 'YES' to a modern Milan, once again leader in the world, 'NO 'to those who live in the past. 'YES' to more assistance and support for the elderly, 'NO' to an administration that raises taxes. 'YES' to more safety and legality, 'NO' to illegal immigration. 'YES' to more aids for mothers." The last scene pictures Letizia Moratti saying "this is my Milan." 


\section{Appendix II: Additional Figures and Tables}

Figure A1 - Opponent's Campaign Slogan, Positive Tone

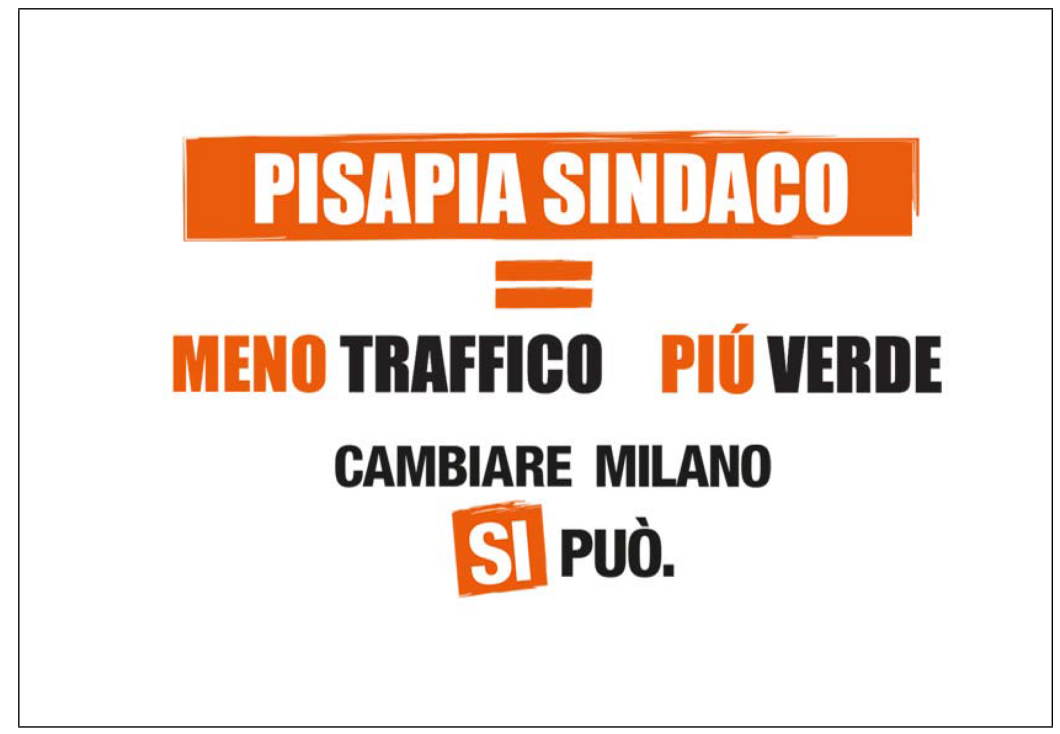

Figure A2 - Opponent's Campaign Slogan, Negative Tone

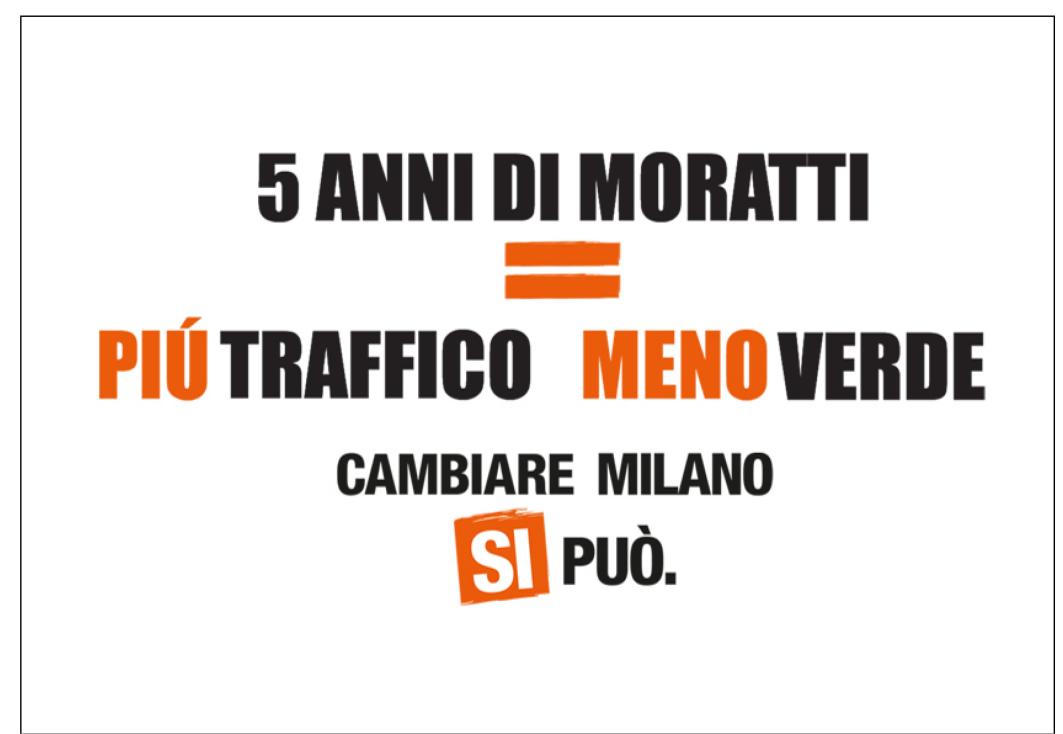



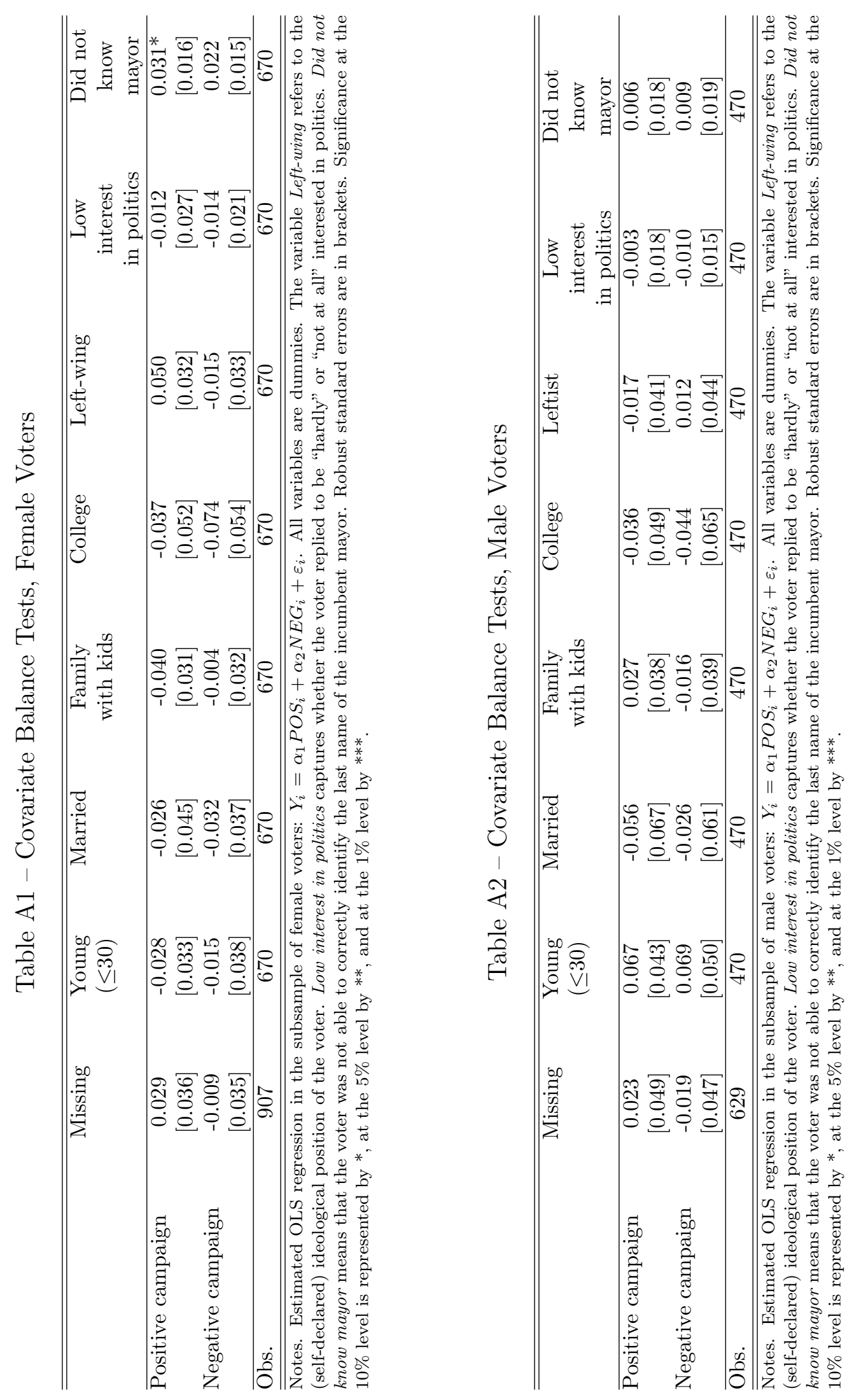
Table A3 - Positive Campaign vs. Negative Campaign by Gender, First Round

\begin{tabular}{lcccc}
\hline \hline & $\begin{array}{c}\text { Turnout } \\
\text { rate }\end{array}$ & $\begin{array}{c}\text { Opponent's } \\
\text { vote share }\end{array}$ & $\begin{array}{c}\text { Incumbent's } \\
\text { vote share }\end{array}$ & $\begin{array}{c}\text { Others' } \\
\text { vote share }\end{array}$ \\
\hline Positive campaign $\left(\alpha_{1}\right)$ & $-0.051^{*}$ & -0.035 & 0.027 & 0.008 \\
& {$[0.029]$} & {$[0.044]$} & {$[0.055]$} & {$[0.048]$} \\
Positive campaign $\times$ Female $\left(\beta_{1}\right)$ & 0.034 & $0.125^{* *}$ & $-0.107^{*}$ & -0.018 \\
& {$[0.037]$} & {$[0.057]$} & {$[0.059]$} & {$[0.065]$} \\
Female & $-0.054^{* *}$ & 0.069 & -0.034 & -0.035 \\
& {$[0.026]$} & {$[0.047]$} & {$[0.047]$} & {$[0.044]$} \\
$P$-value $H 1: \alpha_{1}+\beta_{1}=0$ & 0.556 & $0.062^{*}$ & $0.074^{*}$ & 0.776 \\
\hline Obs. & 842 & 671 & 671 & 671 \\
\hline \hline Notes. Estimated OLS regression in the subsample exposed to any campaign: $Y_{i}=\alpha_{1} P O S_{i}+\beta_{1} P O S_{i} \times F E M A L E_{i}+$ \\
$\delta F E M A L E_{i}+\varepsilon_{i}$. H1) Treatment effect of positive vs. negative campaign for females: $\alpha_{1}+\beta_{1}=0$. Robust standard errors \\
are in brackets. Significance at the $10 \%$ level is represented by *, at the 5\% level by **, and at the $1 \%$ level by ***.
\end{tabular}

Table A4 - Positive Campaign vs. Negative Campaign by Gender, Runoff

\begin{tabular}{lcccc}
\hline \hline & $\begin{array}{c}\text { Expected } \\
\text { turnout }\end{array}$ & $\begin{array}{c}\text { Vote for } \\
\text { opponent }\end{array}$ & $\begin{array}{c}\text { Vote for } \\
\text { incumbent }\end{array}$ & Undecided \\
\hline Positive campaign $\left(\alpha_{1}\right)$ & -0.045 & -0.034 & 0.055 & -0.021 \\
Positive campaign $\times$ Female $\left(\beta_{1}\right)$ & {$[0.030]$} & {$[0.046]$} & {$[0.052]$} & {$[0.037]$} \\
& $0.072^{*}$ & 0.039 & $-0.133^{* *}$ & $0.095^{*}$ \\
Female & {$[0.037]$} & {$[0.053]$} & {$[0.058]$} & {$[0.054]$} \\
& $-0.038^{*}$ & $0.082^{*}$ & -0.043 & -0.039 \\
$P$-value $H 1: \alpha_{1}+\beta_{1}=0$ & {$[0.021]$} & {$[0.048]$} & {$[0.052]$} & {$[0.035]$} \\
Obs. & 0.256 & 0.921 & $0.061^{*}$ & $0.032^{* *}$ \\
\hline \hline Notes. Estimated OLS regression in the subsample exposed to any campaign: $Y_{i}=\alpha_{1} P O S_{i}+\beta_{1} P O S_{i} \times F E M A L E_{i}+$ \\
$\delta F E M A L E_{i}+\varepsilon_{i}$. (H1) Treatment effect of positive vs. negative campaign for females: $\alpha_{1}+\beta_{1}=0$. Robust standard errors \\
are in brackets. Significance at the $10 \%$ level is represented by *, at the 5\% level by **, and at the $1 \%$ level by ***.
\end{tabular}

